\title{
Marine Bacteria versus Microalgae: Who Is the Best for Biotechnological Production of Bioactive Compounds with Antioxidant Properties and Other Biological Applications?
}

\author{
Masoud Hamidi ${ }^{1,2}{ }^{\oplus}$, Pouya Safarzadeh Kozani ${ }^{2}{ }^{\circ}$, Pooria Safarzadeh Kozani ${ }^{3}{ }^{\oplus}$, \\ Guillaume Pierre ${ }^{4}(\mathbb{D})$, Philippe Michaud ${ }^{4}(\mathbb{D})$ and Cédric Delattre ${ }^{4,5, *(D)}$ \\ 1 Food and Drug Research Center, Vice-Chancellery of Food and Drug, Guilan University of Medical Sciences, \\ Rasht P.O. Box 41446/66949, Iran; m.hamidi2008@gmail.com \\ 2 Department of Medical Biotechnology, Faculty of Paramedicine, Guilan University of Medical Sciences, \\ Rasht P.O. Box 44771/66595, Iran; puyasafarzadeh@gmail.com \\ 3 Department of Medical Biotechnology, Faculty of Medical Sciences, Tarbiat Modares University, \\ Tehran P.O. Box 14115/111, Iran; pooriasafarzadeh@gmail.com \\ 4 Université Clermont Auvergne, CNRS, SIGMA Clermont, Institut Pascal, F-63000 Clermont-Ferrand, France; \\ guillaume.pierre@uca.fr (G.P.); philippe.michaud@uca.fr (P.M.) \\ 5 Institut Universitaire de France (IUF), 1 rue Descartes, 75005 Paris, France \\ * Correspondence: cedric.delattre@uca.fr; Tel.: +33-473407423
}

Received: 8 November 2019; Accepted: 23 December 2019; Published: 29 December 2019

\begin{abstract}
Natural bioactive compounds with antioxidant activity play remarkable roles in the prevention of reactive oxygen species (ROS) formation. ROS, which are formed by different pathways, have various pathological influences such as DNA damage, carcinogenesis, and cellular degeneration. Incremental demands have prompted the search for newer and alternative resources of natural bioactive compounds with antioxidant properties. The marine environment encompasses almost three-quarters of our planet and is home to many eukaryotic and prokaryotic microorganisms. Because of extreme physical and chemical conditions, the marine environment is a rich source of chemical and biological diversity, and marine microorganisms have high potential as a source of commercially interesting compounds with various pharmaceutical, nutraceutical, and cosmeceutical applications. Bacteria and microalgae are the most important producers of valuable molecules including antioxidant enzymes (such as superoxide dismutase and catalase) and antioxidant substances (such as carotenoids, exopolysaccharides, and bioactive peptides) with various valuable biological properties and applications. Here, we review the current knowledge of these bioactive compounds while highlighting their antioxidant properties, production yield, health-related benefits, and potential applications in various biological and industrial fields.
\end{abstract}

Keywords: antioxidant; bacteria; carotenoids; exopolysaccharides; microalgae

\section{Introduction}

Antioxidant properties have become a very crucial subject over the past two decades and also the topic of exhaustive research all over the world because of food and pharmaceutical industry demands, which have investigated natural antioxidant sources to produce efficient antioxidant biomolecules as anti-carcinogenic and anti-aging agents [1-4]. It is well-described that during oxidative stress, specific molecules called reactive oxygen species (ROS), such as hydroxyl radical, hydrogen peroxide, nitric acid, or superoxide anions, are generated [1-3]. Consequently, during cellular metabolism, some 
cellular tissue damage can be observed due to the ROS effects on biological macromolecules such as lipids, proteins, and nucleic acids [1-4]. It has been reported that these ROS play significant roles in carcinogenesis and diverse health disorders such as (i) lung injury, (ii) aging, (iii) diabetes mellitus, (iv) inflammatory diseases, and (v) atherosclerosis [1,2,5-12].

From an evolutionary point of view, all living organisms have developed enzymatic and non-enzymatic defense systems, such as the synthesis of (i) glutathione peroxidase/reductase, (ii) superoxide dismutase, (iii) vitamin $\mathrm{C}$ and $\mathrm{E}$, (iv) thioredoxin, and (v) glutathione, to diminish the degree of damage caused by ROS [1-3,6]. Nevertheless, these innate antioxidant biomolecules are not abundant enough to completely prevent oxidative damage. Antioxidant molecule additives are generally used to fight against oxidative damage and to protect human cells by regulating the quantity of ROS. The food industry generally utilizes chemical antioxidants such as butylated hydroxytoluene (BHT), tert-butylhydroquinone (TBHQ), propyl gallate (PG), or butylated hydroxyanisole (BHA) [6-13]. Nonetheless, their use in food and their safety profile are increasingly controversial due to causing liver damage and their potential impact in carcinogenesis [6-15]. This is why, during recent years, safe and natural antioxidant molecules extracted from bioresources are becoming more advantageous in substituting the use of chemical and synthetic antioxidant agents in different fields.

For a long time, most of the antioxidant ingredients such as phenolic compounds, pigments, polysaccharides, and carotenoids were extracted from plants, fruits, and seaweeds [16-22]. Concerning seaweed, relative polysaccharides and pigment compounds have been validated as efficient antioxidants through various techniques such as 1,1-diphenyl-2-picrylhydrazyl radical (DPPH•) scavenging assay, hydroxyl/superoxide radicals $\left(\bullet \mathrm{OH} / \mathrm{O}_{2}{ }^{-} \bullet\right)$ scavenging assay, ferric reducing antioxidant power (FRAP), or lipid peroxidation inhibition capacity assay [18,21-23].

In the immensity of marine biotopes, a large amount of new efficient natural antioxidants continue to be discovered. In fact, the marine environment covers at least three-quarters of the earth's surface, and many microorganisms inhabiting it under extreme conditions have developed very intelligent strategies to grow and adapt. Therefore, marine organisms constitute an inexhaustible source for antioxidant biomolecules among which we can mention (i) enzymes (catalase and superoxide dismutase), (ii) exopolysaccharides, (iii) carotenoids, and (iv) peptides [24-29]. The constant growth of international markets, asking for more natural antioxidant biomolecules, has to be correlated with the industrial expansion of marine microorganisms for high scale-up industrial processes to produce better yields of selected marine antioxidants.

Consequently, this present review aims to give an overview of the advances in the field of antioxidant biomolecules derived from marine microorganisms such as bacteria and microalgae, as well as their current development for potential industrial applications in nutraceutical, cosmeceutical, and pharmaceutical fields.

\section{Description of Marine Organisms}

\subsection{Marine Bacteria}

Bacteria were one of the first forms of life that appeared on earth, and to this day they can be found almost everywhere, from land to marine environments such as oceans and seas. They comprise a wide range of prokaryote microorganisms. Bacteria are very small unicellular organisms (a few micrometers in length) and they appear in various shapes and forms such as spheres, rods, and spirals, and they can live in different environments with various and sometimes extreme conditions such as high temperatures or high salinity. They can also live symbiotically and parasitically with plants and animals, and are crucial components of different ecosystems. Estimations suggest that the earth happens to contain $10^{9}$ taxa of bacteria, whereas the oceans contain $10^{6}$ [30]. As the most widespread and varied members of the microbial groups in oceans, bacteria have important roles in biogeochemical pathways and fluidity of energy and matter [31]. Marine environment-isolated bacteria are believed to be dissimilar from their earth-living counterparts in physiological, biochemical, and molecular 
properties and, consequently, they may produce different metabolites [32]. Marine bacteria inhabit surface waters, from coastal to offshore areas, including general oceanic areas such as blue waters and special condition areas such as hot thermal vents. They have a distribution of $10^{5}$ cells per milliliter $(\mathrm{mL})$, and it is calculated that the oceans altogether contain $3.6 \times 10^{29}$ microbial cells, and that most of this biomass is composed of bacteria, archaea, and other microorganisms such as protists and unicellular fungi. Pseudomonas sp., Vibrio sp., Achromobacter sp., Flavobacterium sp., and Micrococcus sp. are known as the principal seawater bacteria [30].

As reports clarify, of all bioactive metabolites that microorganisms produce, about $40-45 \%$ are generated by Actinomycete bacteria (soil-derived genera, Streptomyces, and Micromonospora) and are currently utilized in clinical fields [32]. Over 50\% of microbial antibiotics are comprised of metabolites derived from these bacteria [33]. On the other hand, not so much is understood about the capabilities of the compounds derived from deep-ocean bacteria [33]. The speed of discovering compounds from old microbial drug producers, such as actinomycetes and hyphomycetes, is declining, and now it is time to reach out to marine bacteria and use their capacities [33]. Research conducted in the past has reported different varieties among the seaweed epiphytic bacterial flora. Lately, scientific communities have paid attention to these bacteria because of their potential for being a source of secondary metabolites with marketing importance [34,35]. Bifurcaria bifurcata epiphytic bacteria are an exceptional source of natural antioxidant and antimicrobial compounds [34]. Some bacteria are believed to have distinct physiological and biological roles due to the pigments they contain [35]. Several newly conducted research studies on pigments, such as violacein, astaxanthin, canthaxanthin, zeaxanthin, rubrolone, and carotenoid derivatives of bacteria from marine sources, confirm their effective radical scavenging activity [35]. Marine organisms living in environments with extreme conditions such as high salinity, low temperature, or extreme pressure have developed specific metabolites to overcome factors threatening their survival, proliferation, facilitated storage, transportation, and turnover of key biological elements [36]. Several pieces of research have reported that the carotenoids produced by halophilic bacteria [37,38], mostly bacterioruberin, show anti-cancer and antioxidant activities [39-45].

\subsection{Microalgae}

As unicellular and photosynthetic microorganisms, microalgae usually live in aqueous environments such as freshwater, blackish, and marine systems, and also non-aqueous environments such as soil and air. They live in both sediments and water column, and some of them are airborne microalgae or photosymbionts with other marine organisms for example mollusks, corals, or sponges [46-48]. As photoautotrophic microorganisms, microalgae use light and inorganic nutrients such as phosphorus, nitrogen, and $\mathrm{CO}_{2}$ to synthesize complex organic macromolecules such as pigments, lipids, nucleic acids, polysaccharides, and proteins, and almost half of the atmospheric oxygen is produced by microalgae [49]. Microalgae are mostly categorized into two groups: prokaryotes such as Cyanobacteria and Prochlorophyta, and eukaryotes such as Chlorophyta, Rhodophyta, Phaeophyta, Bacillariophyta, and Chrysophyta [50]. Estimations indicate that there are about 800,000 species of eukaryotic microalgae and cyanobacteria, of which only 50,000 species have been identified so far [51-53]. Chrysophyta (golden algae), Chlorophyta (green algae), Cyanophyta (blue-green algae), and Bacillariophyta (diatoms) are the four most important categories of microalgae [54]. Microalgae can grow in freshwater, marine, and highly saline environments [55]. Many microalgae species have short reproduction periods, so they do not have to compete for food production, and they can be simply cultivated in significant amounts in closed bioreactors, guaranteeing a theoretically limitless supply of biomass $[50,56]$. Additionally, using clean nutrient media for microalgae culturing grants the ability to control the quality of the microalgal cells, keeping them free of herbicides, pesticides, or any other toxic substances. On the other hand, microalgae could be used to take up valuable nutrients from wastewater [56]. Microalgae culture offers a noteworthy step for wastewater treatment because they provide a tertiary biotreatment coupled with the production of possibly valuable biomass. In fact, using microalgae for wastewater treatment emerges from their different properties such as fast growth 
and nutrient removal capacity. They have this ability to use inorganic nitrogen and phosphorus for their growth. Microalgae can be utilized in wastewater treatment for several different aims, such as reduction of biochemical oxygen demand (BOD), removal of nitrogen and/or phosphorus, inhibition of coliforms, and removal of heavy metals and other toxic organic compounds [57].

The relative simplicity of desired compound purification has accentuated the importance of microalgae as a natural source of bioactive products [58]. A unique property of microalgae is their chemical composition differences dependent on several environmental factors such as temperature, salinity, illumination, $\mathrm{pH}$ value, mineral content, $\mathrm{CO}_{2}$ supply, population density, growth phase, and physiological status; therefore, maximum production of a particular group of chemical compounds could be feasible by optimizing these environmental growth conditions [59]. It is important to state that under normal conditions, microalgae will not produce biologically valuable metabolites or the production yield will become very low. On the other hand, the biosynthesis of these compounds is inducible by exposing microalgae to stressful conditions such as high salinity, strong light, nitrogen deprivation, high temperature, short-term UV radiation, or a mixture of these different conditions. Actually, this property of microalgae is believed to be a very essential element in improving the production of carbohydrates, lipids, carotenoids, and other products [60].

Cyanobacteria are organisms that have unique abilities and are used as food, animal feed (50\% of the present-day world Arthrospira production), and fuel [61-63]. In the old days, cyanobacteria were famous as blue-green algae because of their phycocyanin pigments, which are specific accessory photosynthetic pigments alongside chlorophyll a [63]. Cyanobacteria are a well-known potential and important class of organisms for the extraction of unique, new, and biochemically active natural products. Cyanobacteria such as Spirulina, Anabaena, Nostoc, and Oscillatoria produce great amounts of secondary metabolites that contain $40 \%$ lipopeptides, $9 \%$ amides, $5.6 \%$ amino acids, $4.2 \%$ fatty acids, and $4.2 \%$ macrolides [58]. Lipopeptides of cyanobacteria have various properties such as cytotoxic $(41 \%)$, antitumor (13\%), antibiotic $(12 \%)$, and antiviral activities $(4 \%)$, and the activity of the remaining $18 \%$ is considered as antimalarial, antimycotics, multi-drug resistance reverser, antifeedant, and immunosuppressive [58].

Spirulina is a cyanobacterium that grows in waters with alkaline conditions and has been used as food in Africa for many centuries because of its nutritional benefits, whereas nowadays it is globally utilized as a nutraceutical food supplement. In recent years, many pieces of research have worked on estimating the positive therapeutic effects of Spirulina on a wide range of diseases such as hyperglycerolemia, hypercholesterolemia, cardiovascular diseases, inflammatory diseases, cancer, and viral infections. In fact, hypolipidemic, antioxidant, and anti-inflammatory activities of Spirulina contribute to its anti-cardiovascular effects. The long history of Spirulina consumption as a food source and its approved safety in animal studies backs up the idea of its safety for human applications [64]. Among many Spirulina species, three species including Spirulina platensis (Arthrospira platensis), Spirulina maxima (Arthrospira maxima), and Spirulina fusiformis (Arthrospira fusiformis) are highly investigated because they are edible and have nutritional and therapeutic benefits [65-68].

From thousands of years ago, microalgae have been utilized for nutritional purposes; as an example, Nostoc was consumed to overcome famine in China, Chad, and Mexico. Even though microalgae have been used in traditional ways, microalgae culture is still a modern-day technology [55].

From the beginning of the century, the market size of functional foods derived from microalgae has experienced a five-fold rise and its growth has now relatively matured [41]. Industrial large-scale culture commenced in Japan in the early 1960s with the culture of Chlorella by Nihon Chlorella (Taipei, Taiwan) [69]. Nowadays, microalgae are consumed both as dried whole algae and also as the source for the extraction of worthwhile food supplements such as omega-3 fatty acids and carotenoids [41]. Microalgae products with high nutritional values are available in two forms: one in pure form as extracts, tablets, or capsules, and the other as additives to several food products, such as gums, candy bars, beverages, and pasta [60]. Besides their utilization in human nutrition, microalgae can be added into the feed of a variety of animals from fish to pets, as well as farm animals. About $30 \%$ of 
the present-day world microalgal production is utilized for animal feed applications [61,62]. So far, more than 15,000 new compounds, derived from algal biomass, have been chemically clarified [70]. Commonly, microalgae contain $40-70 \%$ proteins; $12-30 \%$ carbohydrates; $4-20 \%$ lipids; $8-14 \%$ carotene; and considerable amounts of vitamins B1, B2, B3, B6, B12, E, K, and D [59,71]. Production of potentially marketable compounds such as $\beta$-carotene; astaxanthin; polyunsaturated fatty acids (PUFA) such as docosahexaenoic acid (DHA) and eicosapentaenoic acid (EPA); and polysaccharides such as $\beta$-glucan, sterols, chlorophylls, and phycobiliproteins account for the therapeutic and nutritional supplements derived from microalgae [41,72]. Various properties of an alga species such as size, shape, toxicity, and digestibility determine its nutritional value [70].

Antioxidant molecules have gained great interest lately [41], and microalgae stand for a nearly intact resource of natural antioxidants because of their vast biodiversity, which is much more diverse than higher plants [73]. On the other hand, not all groups of microalgae can be applied as natural sources of antioxidants because of their broadly diverse content of products and non-favorable growth rate, as well as some other factors [55]. The leading genera of microalgae in industrial production are Chlorella, Isochrysis, Chaetoceros, Dunaliella, Haematococcus, and Schizochytrium [69,74]. Additionally, prokaryotic microalgae such as Arthrospira and Spirulina and eukaryotic microalgae such as Chlorella are the most commercially valuable microalgae in the field of health food and nutrition supplements $[41,75]$. There are several reports regarding the antioxidant activity calculations corresponding to various kinds of microalgae. For instance, Scenedesmus obliquus strain M2-1 shows the highest total antioxidant capacity (149 \pm 47 antioxidant activity unit) of intracellular extracts [76]. According to Guedes et al. who examined the antioxidant capacity of 23 microalgae species, Scenedesmus obliquus strain M2-1 was the one with the highest total antioxidant activity [76]. Furthermore, specific interest is enforced to isolate microalgae from extreme-condition environments such as hot springs and apply them as good sources of natural products for various biotechnological aims [77-79].

\subsubsection{Chlorella}

Chlorella is a kind of microalgae generally discovered in freshwater environments. It is a reliable source of antioxidants and natural bioactive compounds utilized in the food and pharmaceutical market [80]. They are unicellular photosynthetic microalgae having chlorophyll in their chloroplasts and they also contain lutein and other primary carotenoids such as $\alpha$-carotene and $\beta$-carotene [81]. The most significant substance in Chlorella is $\beta-1,3$-glucan, which is an active immune-stimulator capturing free radicals and decreasing blood lipids [55] with numerous other health-promoting properties such as positive effects on wounds, gastric ulcers, constipation, hypercholesterolemia, and atherosclerosis-prevention activity, as well as antitumor properties [62,82]. Chlorella can also be utilized as a food additive due to the flavor-regulating activity of its coloring agents $[62,83]$.

\subsubsection{Dunaliella}

Dunaliella salina is utilized because of its $\beta$-carotene content that can consist of up to $14 \%$ of its dry weight [84]. Another broadly cultivated microalga is Dunaliella tertiolecta, which is greatly tolerant to salinity and is utilized for $\beta$-carotene harvesting, although it is also famous for the production of anti-carcinogenic compounds such as violaxanthin [55].

\subsubsection{Haematococcus}

Haematococcus pluvialis is a unicellular microalga living freshwater and distributed in many environments around the world [85]. The most progressed product of this microalga is astaxanthin, which is utilized as a food additive or dietary supplement [41]. Besides the fact that the synthetic form of astaxanthin holds more than $95 \%$ of the market, Haematococcus-produced astaxanthin can still be utilized as a natural food colorant [86]. 


\section{Marine Antioxidant Biomolecules}

\subsection{Description and Generalities for Food and Pharmaceutical Applications}

Because ROS-induced oxidative stress is the main reason of inflammatory events leading to many different medical conditions such as cancer, diabetes, neurodegenerative, and cardiovascular diseases, the pursuit for understanding the mechanisms of oxidative stress and also finding novel antioxidant compounds have become the interest for medical scholars [50,87]. Epidemiological investigations have proven a strong correlation between antioxidant utilization and a diminished risk of commonplace chronic diseases such as cardiovascular disease and cancer [88].

The principal concern of the biotechnological industry is to find antioxidant compounds from natural sources to replace artificial antioxidants such as BHA and BHT, which are used in medicinal preparations and packed foods $[89,90]$. The marine environment, covering nearly $70 \%$ of the earth's surface, is a massive source of biodiverse resources including almost 300,000 known species, but it is estimated that this number is only a small percentage of the total number of species that are yet to be discovered. Luckily, investigations regarding marine microbial diversity and ecology, such as phylogenetic studies, have been achievable due to the development of culture-independent techniques such as small ribosomal RNA (rRNA) analysis and metagenomic approaches [30].

Marine microorganisms produce biologically active compounds with novel properties to adapt to extreme marine environmental conditions such as high or low temperature, alkaline or acidic water, and high pressure, as well as limited substrates of the deep-sea water [30]. So far, more than 25,000 of these compounds have been discovered [91], and from 1998 to 2006, around 592 of them have been reviewed for their antitumor and cytotoxic properties in preclinical and clinical studies [33].

Marine biotechnology aims to find efficient novel methods for the production of marine organism-related novel products. These products can have positive effects on human health and can be used as new medicines and antioxidants in the food industry, as well as biofuels in the energy industry [92].

Among different marine organisms, bacteria and microalgae represent themselves as important sources of bioactive compounds [91]. Consumption of microalgae for nutritional purposes is at least a thousand years old. Furthermore, microalgae culture development during recent decades allows for great amounts of algal biomass to be utilized for various applications [55]. Currently, global production of microalgae is predominately directed at various applications because algal biomass has great amounts of pigments, proteins, essential fatty acids, polysaccharides, vitamins, and minerals, which all have gained great attention in the production of natural products in both the nutraceutical and cosmeceutical industries [55]. Some microalgae species such as Arthrospira and Chlorella are well-known in the skincare market [90]. Face and skincare products are a field in which microalgal extracts are majorly utilized, including products such as antiaging creams, refreshing care products, and emollients [90]. Microalgal extracts are also used in sun protection and hair-care products [69].

Antioxidant properties of microalgal extracts result from their structural properties such as phytyl chain, a porphyrin ring, and conjugated double bonds [60]. Furthermore, the activity of each antioxidant varies in different oxidation systems (in vitro, ex vivo, and in vivo). Additional attempts are required to explain the connection between antioxidant activities and their physiological effects in biological systems [88]. The biological activities of antioxidants are tightly correlated with their absorption and metabolism. There are numerous complications in evaluating the true impacts of marine antioxidants. The main difficulties are the various kinds of antioxidants found in foods, their large differences in bioavailability, and the difficulties in finding an answer to the intricate absorption and metabolism mechanisms [88]. Even though some available data propose that health benefits can result from the use of marine natural products, additional epidemiological or clinical studies are nonetheless required to reinforce these statements with more confidence [33]. In fact, regardless of the developing market for antioxidants, uncertainty about the positive effects of dietary antioxidant consumption still lingers on. The relationship between the intake of antioxidant vitamins (for example, 
$\beta$-carotene, vitamin $C$, and vitamin E) or selenium supplements and the incidence and mortality of prostate cancer is still unclear on the basis of the results of a meta-analysis. Also, according to the meta-analysis of randomized controlled trials, antioxidant supplements do not avert skin cancer [33]. Table 1 gathers several famous carotenoids and their applications in different fields in terms of their benefits to human health, as well as some industrial applications. 
Table 1. Several carotenoids and their applications in different fields.

\begin{tabular}{|c|c|c|c|}
\hline Carotenoids & $\begin{array}{l}\text { Examples of Biological Properties, Functions, } \\
\text { and Benefits to Human Health }\end{array}$ & Other Applications & Reference \\
\hline Astaxanthin & 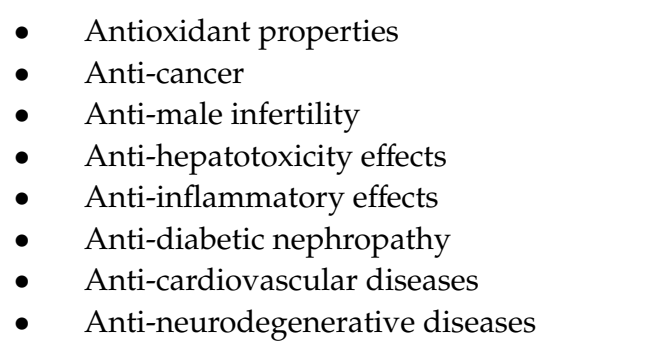 & $\begin{array}{l}\text { - } \quad \text { As a food coloring agent } \\
\text { - } \quad \text { As feed additives }\end{array}$ & [41,93-107] \\
\hline Lutein & $\begin{array}{ll}\text { - } & \text { Antioxidant properties } \\
\text { - } & \text { Anti-cancer } \\
\text { - } & \text { Stroke prevention } \\
\text { - } & \text { Retinitis protective effects } \\
\text { - } & \text { Anti-diabetic retinopathy } \\
\text { - } & \text { Anti-cardiovascular diseases } \\
\text { - } & \text { Helicobacter pylori gastric } \\
\text { - } & \text { Cataract and age-related macular } \\
& \text { degeneration prevention }\end{array}$ & $\begin{array}{l}\text { - } \quad \text { As a food coloring agent } \\
\text { - } \quad \text { Used in poultry feeding }\end{array}$ & {$[41,108-123]$} \\
\hline$\beta$-carotene & $\begin{array}{ll}\text { - } & \text { Antioxidant properties } \\
\text { - } & \text { Liver fibrosis prevention } \\
\text { - } & \text { Provitamin A functionality } \\
\text { - } & \text { Anti-neurodegenerative diseases } \\
\text { - } & \text { Skin photoprotection against UV light } \\
\text { - } & \text { Acute and chronic coronary } \\
& \text { syndromes prevention }\end{array}$ & $\begin{array}{l}\text { - } \quad \text { As a food coloring agent } \\
\text { - As food supplements }\end{array}$ & $\begin{array}{c}{[98,106,124-} \\
136]\end{array}$ \\
\hline
\end{tabular}


Table 1. Cont.

\begin{tabular}{|c|c|c|c|}
\hline Carotenoids & $\begin{array}{l}\text { Examples of Biological Properties, Functions, } \\
\text { and Benefits to Human Health }\end{array}$ & Other Applications & Reference \\
\hline Lycopene & $\begin{array}{ll}\text { - } & \text { Antioxidant properties } \\
\text { - } & \text { Anti-cancer } \\
\text { - } & \text { Gene regulation activity } \\
\text { - } & \text { Antiulcer activity } \\
\text { - } & \text { Radiation protection }\end{array}$ & - As a food coloring agent & $\begin{array}{l}{[39,41,137-} \\
141]\end{array}$ \\
\hline Canthaxanthin & $\begin{array}{ll}\text { - } & \text { Antioxidant properties } \\
\text { - } & \text { Anti-cardiovascular diseases } \\
\text { - } & \text { Tan color creation } \\
\text { - } & \text { Antitumoral activity } \\
\text { - } & \text { Provitamin a functionality } \\
\text { - } & \text { Immune system stimulation }\end{array}$ & $\begin{array}{l}\text { - As a food coloring agent } \\
\text { As an additive for the } \\
\text { feed of dogs, cats, } \\
\text { ornamental fish, birds, } \\
\text { and other pets }\end{array}$ & $\begin{array}{l}{[39,41,81,107} \\
142-148]\end{array}$ \\
\hline Fucoxanthin & $\begin{array}{ll}\text { - } & \text { Antioxidant properties } \\
\text { - } & \text { Anti-obesity } \\
\text { - } & \text { Anti-cancer } \\
\text { - } & \text { Anti-malarial effects } \\
\text { - } & \text { Bone-protective effects } \\
\text { - } & \text { Anti-inflammatory effects } \\
\text { - } & \text { Anti-hepatotoxicity effects }\end{array}$ & - $\quad$ N.A.* & $\begin{array}{l}{[81,96,149-} \\
156]\end{array}$ \\
\hline Zeaxanthin & $\begin{array}{ll}\text { - } & \text { Antioxidant properties } \\
\text { - } & \text { Anti-diabetic retinopathy } \\
\text { - } & \text { Acute and chronic coronary } \\
\text { - } & \text { Syndromes prevention } \\
\text { - } & \text { degeneract and age-related macular } \\
\text { - } & \text { Visual function maintenance } \\
\text { - } & \text { Anti-cardiovascular diseases }\end{array}$ & $\begin{array}{l}\text { - } \quad \text { As a food coloring agent } \\
\text { - } \quad \text { Used in poultry feeding }\end{array}$ & $\begin{array}{r}{[41,134,136} \\
151,157-171]\end{array}$ \\
\hline
\end{tabular}


Table 1. Cont.

\begin{tabular}{|c|c|c|c|}
\hline Carotenoids & $\begin{array}{l}\text { Examples of Biological Properties, Functions, } \\
\text { and Benefits to Human Health }\end{array}$ & Other Applications & Reference \\
\hline$\beta$-Cryptoxanthin & 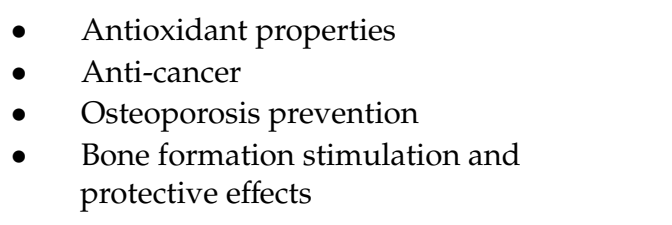 & - $\quad$ N.A.* & {$[151,172-178]$} \\
\hline Bacterioruberin & $\begin{array}{l}\text { - } \quad \text { Antioxidant properties } \\
\text { - } \quad \text { Anti-cancer }\end{array}$ & - $\quad$ N.A.* & [39] \\
\hline Sioxanthin & - Antioxidant properties & - $\quad$ N.A.* & [179] \\
\hline Salinixanthin & $\begin{array}{l}\text { - } \\
\text { - } \\
\text { Antioxidant properties } \\
\end{array}$ & - $\quad$ N.A.* & [39] \\
\hline Saproxanthin & $\begin{array}{l}\text { - } \\
\text { - }\end{array}$ & - $\quad$ N.A.* & {$[151,180]$} \\
\hline Violaxanthin & $\begin{array}{l}\text { - } \quad \text { Antioxidant properties } \\
\text { - } \quad \text { Anti-inflammatory effects in macrophages }\end{array}$ & - As a food coloring agent & {$[41,179,181]$} \\
\hline Myxol & $\begin{array}{l}\text { - } \\
\text { - } \quad \text { Antioxidant property } \\
\text { Antincer }\end{array}$ & - $\quad$ N.A.* & {$[151,182]$} \\
\hline Echinenone & - $\quad$ Antioxidant properties & - $\quad$ N.A.* & {$[81,179,183]$} \\
\hline Phytoene & $\begin{array}{ll}\text { - } & \text { Antioxidant properties } \\
\text { - } & \text { Antitumoral activity }\end{array}$ & - $\quad$ N.A.* & {$[39,144,184]$} \\
\hline Siphonaxanthin & - Antiproliferative activity & - $\quad$ N.A.* & [185] \\
\hline
\end{tabular}

N.A.*: not available. 


\subsection{Carotenoids}

Carotenoids are lipophilic compounds appearing in different colors such as yellow, orange, and red. They are the most prevalent and frequent pigments found in nature $[186,187]$ with more than 700 of them identified to this day $[38,56]$. Most carotenoids have a mutual C40 isoprene unit backbone structure, called terpenoid, and are categorized into two groups: carotenes and xanthophylls. Carotenes are only hydrocarbon and xanthophylls are the oxygenated byproducts of carotenes. Xanthophylls are quite hydrophilic compounds because of the hydroxyl and keto groups they have at the end rings [27]. The yellow, orange, and red hue coloring in higher plants, algae, bacteria, fungi, and some animals result from carotenoids. In all photosynthetic organisms, carotenoids are the principal non-chlorophyll accessory pigments that are necessary for light-harvesting and photoprotection [142]. Carotenoids are also capable of photo-protecting the photosynthetic machinery from extra light by capturing free radicals [188]. On the basis of direct or indirect engagement of carotenoids in photosynthesis, they are divided into two groups: primary carotenoids, such as $\alpha$-carotene, $\beta$-carotene, and lutein, which are directly engaged in photosynthesis and are vital for cellular survival, and secondary carotenoids, such as astaxanthin and canthaxanthin, which are produced and stored in a process called carotenogenesis during the time that bacteria or microalgae are subjected to particular environmental stimuli $[189,190]$.

A diverse range of commercial applications emerge from the biological properties of carotenoids [87]. Lately, significant attention has been drawn to carotenoids because of their biotechnological applications and their probable valuable applications in the field of human healthcare, food processing, pharmaceuticalsm and cosmetics $[142,191]$. They are also famous and accepted as valuable antioxidants with available proof that they are engaged in other biological functions such as gene expression regulatory effects on intracellular and intercellular signaling [192]. Furthermore, because of their coloring properties, they have customarily been used in food and animal feed. Additionally, they are also known to enhance consumer perception of quality, for instance, adding carotenoids to fish feed will pass on color to farmed salmon [87].

In a search performed in PubMed, Scopus, and Web of Science, where "carotenoids" and "human health" were used as keywords, about 6000, 3000, and 6000 results were respectively found, indicating the promising effects of carotenoids on human health [41]. It is important to state that these findings are still inadequate because only a fraction of them have been conducted in humans [41].

Marine bacteria and microalgae act as a massive source of diverse forms of carotenoids. In these microorganisms, carotenoids have different functions such as regulating mechanisms against oxidative stress, granting cellular colorings, and administering photoprotection. It is notable to emphasize that particular carotenoids such as salinixanthin or bacterioruberin are exclusively produced by specific extremophilic bacteria and microalgae [41]. Microalgae have lately been in the center of interest among other sources of carotenoids because of their many advantages, such as reasonably easy cultivation, rapid replicability, ecological sustainability, and capability of adaptation to changing environmental conditions by creating a wide range of secondary metabolites. Biosynthesis of carotenoids in both bacteria and microalgae could be induced by either modification of cultivation conditions or genetic engineering methods.

Figures 1 and 2 display simplified diagrams of several microalgae and marine bacteria and the carotenoids they prominently produce.

Green microalgae can produce all of the xanthophylls biosynthesized by higher plants alongside some additional ones. In cyanobacteria and oxygenic photosynthetic bacteria, most of the xanthophylls are related to chlorophyll-binding polypeptides of the photosynthetic apparatus [193]. It is also important to mention that carotenes and xanthophylls are produced inside the plastids of green microalgae and are stored exclusively there. On the other hand, cytoplasmic storage of secondary xanthophylls has also been detected in some green microalgae such as astaxanthin in Haematococcus sp., which suggests the existence of an extra-plastid site for carotenoid biosynthesis. Otherwise, exportation and storage of chloroplast-synthesized xanthophylls have been detected and explained by a proposed theory that they can be in reach of all cellular compartments that need them [194-196]. 


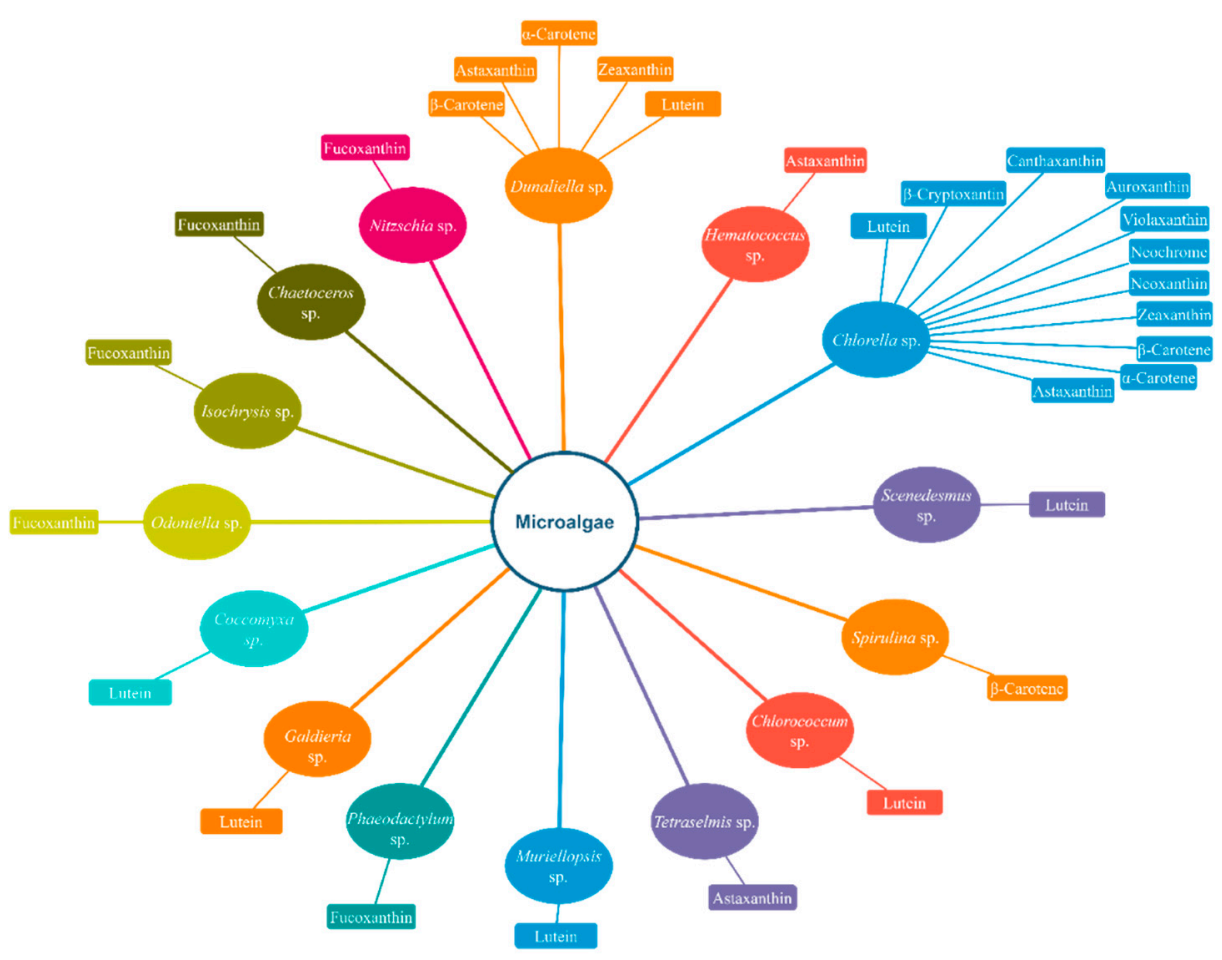

Figure 1. Several famous microalgae and the carotenoids produced by them. Only carotenoids produced at a high amount are mentioned in the diagram.

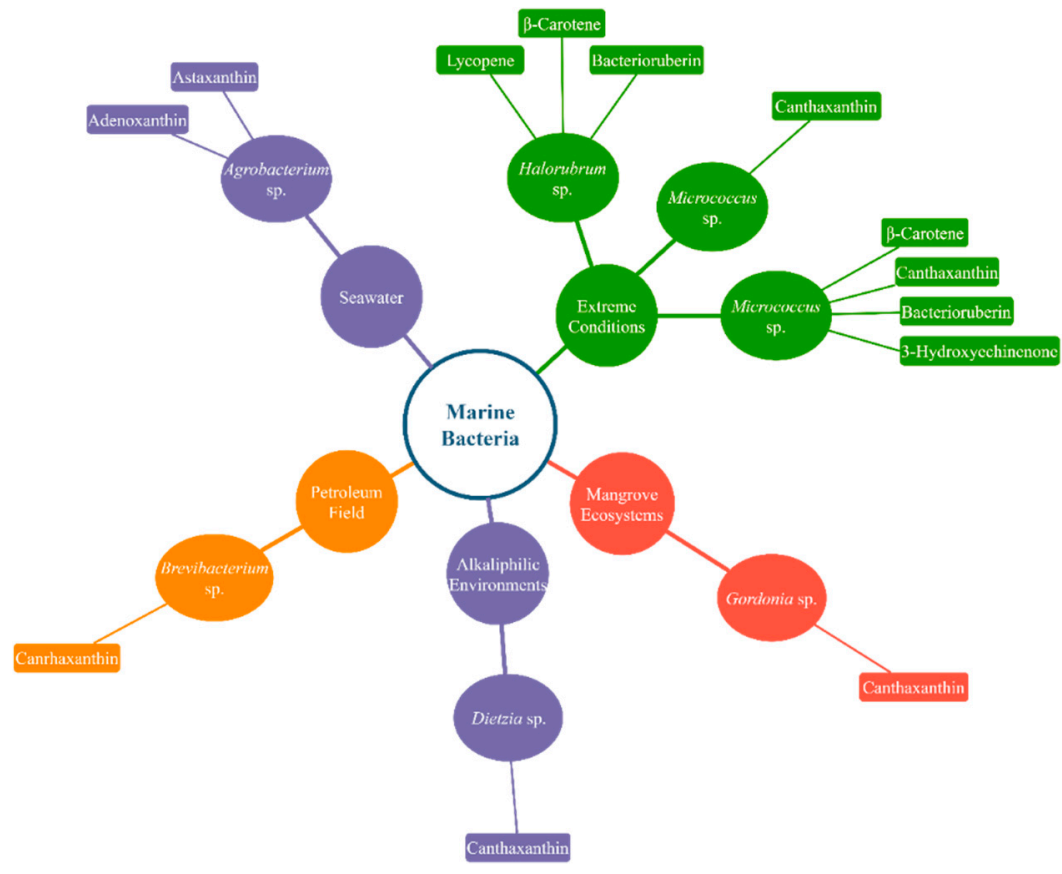

Figure 2. Various carotenoid-producing marine bacteria and their natural growth condition. Only a few well-known marine bacteria and the carotenoids they produce at a high rate are featured in the diagram.

To this day, the in vitro synthesis of carotenoids has maintained their mass production. Nevertheless, the developing present-day standards for nature-loving routines and a healthy way of life have offered a search for natural bio-compounds as alternatives to synthetic ones. Recently, microalgae and bacteria biomass are being utilized as naturally accessible carotenoid sources. This is a great new way forward, in contrast to the in vitro synthesis of carotenoids, which is costly and 
produces compounds that are sometimes biologically inert [41]. Because the production of carotenoids might be generally simpler in marine bacteria and microalgae, they have been known as good natural sources for carotenoids among other regular natural sources [41]. The production of bioactive compounds from marine bacteria and microalgae has been recently studied using current methods such as transcriptomics, genomics, and proteomics [41]. Marine bacteria and microalgae, besides their ability to produce novel bioactive compounds, propose special potentials for carotenoid mass-production, for instance, the danger of contamination with different microorganisms is diminished because of the high-saltiness conditions utilized in their culture media. This characteristic is more highlighted when extreme halophilic marine microorganisms such as Haloarchaea are utilized as the common source of bioactive compounds [37,38,41].

Marine bacteria and microalgae that have the ability to produce carotenoids in high amounts have been the center of attention of researchers and biotechnology companies for the past 30 years. A reason for this attention is the high demand for the biocompounds that are derived from these natural sources, which in itself shows that consumers prefer natural products rather than synthetic forms [41]. The USA and Europe are the business markets where the interest in carotenoids is at its highest level [41], and the worldwide market for carotenoids is expected to reach as high as 1.7 billion United States dollars as of 2022 [41].

Astaxanthin and $\beta$-carotene, as the most prevalent carotenoids, are briefly discussed in the following sections.

Tables 2 and 3 show several carotenoids produced by a few famous microalgae and marine bacteria, as well as the amount of their production evaluated in different studies under optimized conditions. 
Table 2. Some carotenoid-producing microalgae.

\begin{tabular}{|c|c|c|c|c|c|}
\hline Name & Carotenoid(s) & Molecular Formula & Production Yield & Source & Reference \\
\hline \multirow{5}{*}{ Dunaliella sp. } & $\beta$-carotene & $\mathrm{C}_{40} \mathrm{H}_{56}$ & $100 \mathrm{mg} / \mathrm{L}$ & Dunaliella salina & {$[197,198]$} \\
\hline & Astaxanthin & $\mathrm{C}_{40} \mathrm{H}_{52} \mathrm{O}_{4}$ & $40-45 \mathrm{mg} / \mathrm{g}$ & Dunaliella salina & [199] \\
\hline & $\alpha$-carotene & $\mathrm{C}_{40} \mathrm{H}_{56}$ & $2.7 \pm 0.5 \mathrm{mg} / \mathrm{g}$ & Dunaliella salina & [200] \\
\hline & Zeaxanthin & $\mathrm{C}_{40} \mathrm{H}_{56} \mathrm{O}_{2}$ & $11.3 \pm 1.6 \mathrm{mg} / \mathrm{g}$ & Dunaliella salina & [200] \\
\hline & Lutein & $\mathrm{C}_{40} \mathrm{H}_{56} \mathrm{O}_{2}$ & $6.6 \pm 0.9 \mathrm{mg} / \mathrm{g}$ & Dunaliella salina & [200] \\
\hline Hematococcus sp. & Astaxanthin & $\mathrm{C}_{40} \mathrm{H}_{52} \mathrm{O}_{4}$ & $357 \mathrm{mg} / \mathrm{L}$ & Haematococcus pluvialis & [201] \\
\hline \multirow{11}{*}{ Chlorella sp. } & Astaxanthin & $\mathrm{C}_{40} \mathrm{H}_{52} \mathrm{O}_{4}$ & $10.3 \mathrm{mg} / \mathrm{L}$ & Chlorella zofingiensis & [202] \\
\hline & Lutein & $\mathrm{C}_{40} \mathrm{H}_{56} \mathrm{O}_{2}$ & $153,009.7 \mu \mathrm{g} / \mathrm{g}$ & Chlorella pyrenoidosa & [203] \\
\hline & $\beta$-cryptoxantin & $\mathrm{C}_{40} \mathrm{H}_{56} \mathrm{O}$ & $334.9 \mu \mathrm{g} / \mathrm{g}$ & Chlorella pyrenoidosa & [203] \\
\hline & Canthaxanthin & $\mathrm{C}_{40} \mathrm{H}_{52} \mathrm{O}_{2}$ & $8.5 \mathrm{mg} / \mathrm{g}$ & Chlorella zofingiensis & [27] \\
\hline & Auroxanthin & $\mathrm{C}_{40} \mathrm{H}_{56} \mathrm{O}_{4}$ & $38.5 \mu \mathrm{g} / \mathrm{g}$ & Chlorella pyrenoidosa & [203] \\
\hline & Violaxanthin & $\mathrm{C}_{40} \mathrm{H}_{56} \mathrm{O}_{4}$ & $38.1 \mu \mathrm{g} / \mathrm{g}$ & Chlorella pyrenoidosa & [203] \\
\hline & Neochrome & $\mathrm{C}_{40} \mathrm{H}_{56} \mathrm{O}_{4}$ & $65.2 \mu \mathrm{g} / \mathrm{g}$ & Chlorella pyrenoidosa & [203] \\
\hline & Neoxanthin & $\mathrm{C}_{40} \mathrm{H}_{56} \mathrm{O}_{4}$ & $199.7 \mu \mathrm{g} / \mathrm{g}$ & Chlorella pyrenoidosa & [203] \\
\hline & Zeaxanthin & $\mathrm{C}_{40} \mathrm{H}_{56} \mathrm{O}_{2}$ & $2170.3 \mu \mathrm{g} / \mathrm{g}$ & Chlorella pyrenoidosa & [203] \\
\hline & $\beta$-carotene & $\mathrm{C}_{40} \mathrm{H}_{56}$ & $4314.3 \mu \mathrm{g} / \mathrm{g}$ & Chlorella pyrenoidosa & [203] \\
\hline & $\alpha$-carotene & $\mathrm{C}_{40} \mathrm{H}_{56}$ & $4232.5 \mu \mathrm{g} / \mathrm{g}$ & Chlorella pyrenoidosa & [203] \\
\hline Scenedesmus sp. & Lutein & $\mathrm{C}_{40} \mathrm{H}_{56} \mathrm{O}_{2}$ & $3.8 \mathrm{mg} / \mathrm{L}$. day & Scenedesmus almeriensis & {$[204,205]$} \\
\hline Spirulina sp. & $\beta$-carotene & $\mathrm{C}_{40} \mathrm{H}_{56}$ & $296 \mathrm{mg} / \mathrm{kg}$ & Spirulina platensis & [206-209] \\
\hline Chlorococcum sp. & Lutein & $\mathrm{C}_{40} \mathrm{H}_{56} \mathrm{O}_{2}$ & $1.05 \mathrm{mg} / \mathrm{L} . \mathrm{h}$ & Chlorococcum citriforme & [210] \\
\hline Tetraselmis sp. & Astaxanthin & $\mathrm{C}_{40} \mathrm{H}_{52} \mathrm{O}_{4}$ & $2.3 \mathrm{mg} / \mathrm{g}$ & Tetraselmis suecica & [211] \\
\hline Muriellopsis sp. & Lutein & $\mathrm{C}_{40} \mathrm{H}_{56} \mathrm{O}_{2}$ & $35 \mathrm{mg} / \mathrm{L}$ & Not mentioned & [194] \\
\hline Phaeodactylum sp. & Fucoxanthin & $\mathrm{C}_{42} \mathrm{H}_{58} \mathrm{O}_{6}$ & $15.7 \mathrm{mg} / \mathrm{g}$ & Phaeodactylum tricornutum & [212] \\
\hline Galdieria sp. & Lutein & $\mathrm{C}_{40} \mathrm{H}_{56} \mathrm{O}_{2}$ & $0.6 \pm 0.1 \mathrm{mg} / \mathrm{g}$ & Galdieria sulphuraria & [213] \\
\hline Coccomyxa sp. & Lutein & $\mathrm{C}_{40} \mathrm{H}_{56} \mathrm{O}_{2}$ & $5-6 \mathrm{~g} / \mathrm{L}$ & Coccomyxa onubensis & [214] \\
\hline Odontella sp. & Fucoxanthin & $\mathrm{C}_{42} \mathrm{H}_{58} \mathrm{O}_{6}$ & $80 \mathrm{mg} / \mathrm{L}$ & Odontella aurita & [215] \\
\hline Isochrysis sp. & Fucoxanthin & $\mathrm{C}_{42} \mathrm{H}_{58} \mathrm{O}_{6}$ & $18.23 \pm 0.54 \mathrm{mg} / \mathrm{g}$ & Isochrysis aff. Galbana & [216] \\
\hline Chaetoceros sp. & Fucoxanthin & $\mathrm{C}_{42} \mathrm{H}_{58} \mathrm{O}_{6}$ & $2.24 \pm 0.01 \mathrm{mg} / \mathrm{g}$ & Chaetoceros gracilis & [216] \\
\hline Nitzschia sp. & Fucoxanthin & $\mathrm{C}_{42} \mathrm{H}_{58} \mathrm{O}_{6}$ & $4.92 \pm 0.11 \mathrm{mg} / \mathrm{g}$ & Nitzschia closterium & [216] \\
\hline
\end{tabular}


Table 3. Some carotenoid-producing marine bacteria.

\begin{tabular}{|c|c|c|c|c|c|}
\hline Name & Carotenoid(s) & Molecular Formula & Production Yield & Source & Reference \\
\hline Gordonia sp. & Canthaxanthin & $\mathrm{C}_{40} \mathrm{H}_{52} \mathrm{O}_{2}$ & $0.73 \mathrm{mg} / \mathrm{L}$ & Gordonia jacobaea $M V-1$ & [217] \\
\hline Micrococcus sp. & Canthaxanthin & $\mathrm{C}_{40} \mathrm{H}_{52} \mathrm{O}_{2}$ & $1.70 \mathrm{mg} / \mathrm{L}$ & Micrococcus roseus & [218] \\
\hline Dietzia sp. & Canthaxanthin & $\mathrm{C}_{40} \mathrm{H}_{52} \mathrm{O}_{2}$ & $5.31 \mathrm{mg} / \mathrm{L}$ & Dietzia natronolimnaea HS-1 & [219] \\
\hline Brevibacterium sp. & Canthaxanthin & $\mathrm{C}_{40} \mathrm{H}_{52} \mathrm{O}_{2}$ & $9.3 \mathrm{mg} / \mathrm{L}$ & Brevibacterium KY-4313 & [220] \\
\hline Haloferax sp. & $\begin{array}{c}\text { Canthaxanthin } \\
\beta \text {-carotene } \\
\text { Bacterioruberin } \\
\text { 3-Hydroxyechinenone }\end{array}$ & $\begin{array}{c}\mathrm{C}_{40} \mathrm{H}_{52} \mathrm{O}_{2} \\
\mathrm{C}_{40} \mathrm{H}_{56} \\
\mathrm{C}_{50} \mathrm{H}_{76} \mathrm{O}_{4} \\
\mathrm{C}_{40} \mathrm{H}_{54} \mathrm{O}_{2} \\
\end{array}$ & $\begin{array}{c}2,194.09 \pm 0.3 \mu \mathrm{g} / \mathrm{L} \\
189.91 \pm 0.5 \mu \mathrm{g} / \mathrm{L} \\
3,818.45 \pm 0.01 \mu \mathrm{g} / \mathrm{L} \\
250.95 \pm 0.9 \mu \mathrm{g} / \mathrm{L}\end{array}$ & $\begin{array}{l}\text { Haloferax alexandrinus } \\
\text { Haloferax alexandrinus } \\
\text { Haloferax alexandrinus } \\
\text { Haloferax alexandrinus }\end{array}$ & $\begin{array}{l}{[221]} \\
{[221]} \\
{[221]} \\
{[221]}\end{array}$ \\
\hline Agrobacterium sp. & $\begin{array}{l}\text { Astaxanthin } \\
\text { Adonixanthin }\end{array}$ & $\begin{array}{l}\mathrm{C}_{40} \mathrm{H}_{52} \mathrm{O}_{4} \\
\mathrm{C}_{40} \mathrm{H}_{54} \mathrm{O}_{3} \\
\end{array}$ & $\begin{array}{c}89.7 \mu \mathrm{g} / \mathrm{L} \\
323.38 \mu \mathrm{g} / \mathrm{L}\end{array}$ & $\begin{array}{l}\text { Agrobacterium aurantiacum } \\
\text { Agrobacterium aurantiacum }\end{array}$ & $\begin{array}{l}{[222]} \\
{[222]}\end{array}$ \\
\hline Halorubrum sp. & $\begin{array}{c}\text { Bacterioruberin } \\
\text { Lycopene } \\
\beta \text {-carotene }\end{array}$ & $\begin{array}{c}\mathrm{C}_{50} \mathrm{H}_{76} \mathrm{O}_{4} \\
\mathrm{C}_{40} \mathrm{H}_{56} \\
\mathrm{C}_{40} \mathrm{H}_{56} \\
\end{array}$ & $\begin{array}{l}11.47 \mathrm{mg} / \mathrm{L} \\
0.104 \mathrm{mg} / \mathrm{L} \\
0.128 \mathrm{mg} / \mathrm{L}\end{array}$ & $\begin{array}{l}\text { Halorubrum sp. TBZ126 } \\
\text { Halorubrum sp. TBZ126 } \\
\text { Halorubrum sp. TBZ126 }\end{array}$ & $\begin{array}{l}{[223]} \\
{[223]} \\
{[223]} \\
\end{array}$ \\
\hline Gramella sp. & Zeaxanthin & $\mathrm{C}_{40} \mathrm{H}_{56} \mathrm{O}_{2}$ & N.D.* & $\begin{array}{c}\text { Gramella oceani } \\
\text { Gramella planctonica }\end{array}$ & $\begin{array}{l}{[167,224]} \\
{[224,225]}\end{array}$ \\
\hline Aquibacter sp. & Zeaxanthin & $\mathrm{C}_{40} \mathrm{H}_{56} \mathrm{O}_{2}$ & N.D.* & Aquibacter zeaxanthinifaciens & {$[224,225]$} \\
\hline Kordia sp. & Zeaxanthin & $\mathrm{C}_{40} \mathrm{H}_{56} \mathrm{O}_{2}$ & N.D.* & Kordia aquimaris & {$[224,225]$} \\
\hline Saprospira sp. & $3 R$-saproxanthin & $\mathrm{C}_{40} \mathrm{H}_{56} \mathrm{O}_{2}$ & N.D.* & Saprospira grandis & {$[226,227]$} \\
\hline Flavobacterium sp. & $3 R, 2^{\prime} S$-myxol & $\mathrm{C}_{40} \mathrm{H}_{56} \mathrm{O}_{3}$ & N.D.* & Flavobacterium sp. strain P99-3 & {$[226,227]$} \\
\hline Anabaena sp. & 3R,2'S-myxol & $\mathrm{C}_{40} \mathrm{H}_{56} \mathrm{O}_{3}$ & N.D.* & Anabaena variabilis & {$[226,227]$} \\
\hline Halobacterium sp. & $\alpha$-bacterioruberin & $\mathrm{C}_{50} \mathrm{H}_{76} \mathrm{O}_{4}$ & N.D.* & $\begin{array}{l}\text { Halobacterium salinarum strain } \\
\text { NRC-1 and strain R1 } \\
\text { Halobacterium sodomense }\end{array}$ & {$[39,228]$} \\
\hline Haloarcula sp. & $\alpha$-bacterioruberin & $\mathrm{C}_{50} \mathrm{H}_{76} \mathrm{O}_{4}$ & N.D.* & Haloarcula vallismortis & {$[39,228]$} \\
\hline Salinibacter sp. & Salinixanthin & $\mathrm{C}_{61} \mathrm{H}_{92} \mathrm{O}_{9}$ & N.D.* & Salinibacter ruber & {$[228,229]$} \\
\hline Mesoflavibacter sp. & Zeaxanthin & $\mathrm{C}_{40} \mathrm{H}_{56} \mathrm{O}_{2}$ & N.D.* & $\begin{array}{l}\text { Mesoflavibacter } \\
\text { zeaxanthinifaciens }\end{array}$ & {$[224,230]$} \\
\hline $\begin{array}{l}\text { Zeaxanthinibacter } \\
\text { sp. }\end{array}$ & Zeaxanthin & $\mathrm{C}_{40} \mathrm{H}_{56} \mathrm{O}_{2}$ & N.D.* & ZeaxanthinibacterEnoshimensis & {$[224,231]$} \\
\hline Muricauda sp. & Zeaxanthin & $\mathrm{C}_{40} \mathrm{H}_{56} \mathrm{O}_{2}$ & N.D.* & Muricauda lutaonensis & {$[224,232]$} \\
\hline Siansivirga sp. & Zeaxanthin & $\mathrm{C}_{40} \mathrm{H}_{56} \mathrm{O}_{2}$ & N.D.* & Siansivirga zeaxanthinifaciens & {$[224,233]$} \\
\hline
\end{tabular}




\subsubsection{Astaxanthin}

Astaxanthin is a red-pink-colored xanthophyll carotenoid possessing two extra oxygenated gatherings on each ring, granting it improved antioxidant properties [152]. Astaxanthin has the capability to connect across the whole-cell membrane from within to the outside, which gives it a stronger biological activity than other antioxidants [41]. As reports claim, the antioxidant properties of astaxanthin are a few folds higher than those of other carotenoids and tocopherols. The valuable health impacts such as photoprotection of eyes and skin, anti-inflammatory characteristics, heart health improvement, and cancer prevention properties of astaxanthin may result from its strong antioxidant activity [88]. A few studies have shown that astaxanthin, when utilized as a dietary enhancer (E number E161j), has potential helpful consequences for human wellbeing. The biotechnological production of astaxanthin from different sources has been investigated in detail to accomplish its production on a vast scale for a few commercial applications. Astaxanthin products, in different dosage forms such as tablets, cases, syrups, oils, delicate gels, creams, biomass, and granulated powders, are widely utilized for commercial applications [41]. A commercial form of astaxanthin, named Zanthin, which is a supercritical carbon dioxide derived from Haematococcus pluvialis, has received U.S. Food and Drug Administration (FDA) approval for its use as a dietary supplement [234].

Haematococcus pluvialis, Chlorella zofigiensis, Chlorella vulgaris, and Chlorococcum sp. are known as the main natural sources of astaxanthin. The overall production yield attributed to Haematococcus pluvialis surpasses any other natural sources, accounting for up to $4-5 \%$ of its dry weight [235]. Haematococcus pluvialis is currently cultivated at industrial scales because it can produce more than $3 \mathrm{~g}$ of astaxanthin $\mathrm{kg} / \mathrm{L}$ dry biomass [194]. It is also valuable to mention that astaxanthin, derived from marine sources, has higher levels of biological activities than those of its soil-derived counterparts [88].

Companies such as Cyanotech and Aquasearch have developed a two-stage strategy for producing astaxanthin by Haematococcus sp. The first stage, named the "green" stage, is performed under optimal growth conditions and produces green biomass. The second stage, named the "red" stage, subjects microalgae to unfavorable environmental conditions, leading to astaxanthin collection. In mass production facilities, this method produces $2.2 \mathrm{mg} / \mathrm{L}$ astaxanthin, whereas at the laboratory scale and under nonstop illumination, maximum astaxanthin production of $11.5 \mathrm{mg} / \mathrm{L}$ is achievable [236].

\subsection{2. $\beta$-Carotene}

$\beta$-carotene is a strong orange-colored pigment mostly found in green-colored leafy plants (such as parsley, spinach, and broccoli), fruits (such as mandarin and peach), and a few vegetables (such as carrot and pumpkin) [237]. It is utilized as a food coloring agent (E number E160) [135] and also acts as a precursor and inactive form of vitamin A in nature (synthesized from carotenoids with the help of the enzyme $\beta$-carotene 15,150-monooxygenase). After biosynthesis, vitamin A conversion into retinoid takes place to prevent hypervitaminosis $\mathrm{A}[238,239]$.

Several $\beta$-carotene isomers such as all-trans- $\beta$-carotene as well as other minor carotenoids that have been extracted from Dunaliella salina (which is a halotolerant microalga) are known as good antioxidant molecules [234]. $\beta$-Carotene, which is the principal carotenoid produced by Dunaliella salina (more than $10 \%$ of its dry weight) [91], was the first algal product to be commercialized [234]. The optimum salinity of $22 \%(w / v)$, which is $7-8$ times higher than seawater salinity, is suitable for the growth of Dunaliella salina, making it the most halophilic eukaryotic microalga to produce $\beta$-carotene and suggesting the potential of this microalga for open-air culture [234].

Investigations have demonstrated that besides antioxidant properties, $\beta$-carotene has many other benefits to human health, such as liver fibrosis prevention, provitamin A functionality, night blindness prevention, anti-neurodegenerative disease properties, and skin photoprotection against UV light, as well as acute and chronic coronary syndrome prevention. 


\subsubsection{Other Carotenoids}

In this section, we briefly discuss the carotenoids that are not widespread, as well as rare carotenoids that are only found in several specific extreme-condition marine bacteria and microalgae.

So far, commercial production of some particular carotenoids from several specific microalgae has been reported-cases such as Muriellopsis sp. for lutein production because of its high growth rate and high lutein content (up to $35 \mathrm{mg} / \mathrm{L}$ ) [194], as well as Chlorella vulgaris being reported as a high producer of lutein [208]. Also, Chlorella ellipsoidea is a good producer of violaxanthin alongside xanthophylls such as antheraxanthin and zeaxanthin [208].

Halophilic Archaea, from the families Halobacteriaceae and Haloferacaceae, have a red color that is mostly results from a special carotenoid they contain named "bacterioruberin". As recent investigations regarding the production of bacterioruberin show, the production of this rare carotenoid might be simply improved by enforcing modifications on light frequency, oxygen availability, $\mathrm{pH}$, salinity, or temperature [41,223]. Furthermore, Haloarchaea are also organisms that produce several rare carotenoids such as salinixanthin $[37,38]$. It is worth mentioning that some researchers such as Shindo and Gamone and their colleagues consider saproxanthin, sioxanthin, and siphonaxanthin as rare carotenoids in their works and articles [41].

New strains of marine bacteria from the family Flavobacteriaceae have been shown to have rare carotenoids such as saproxanthin and myxol with antioxidant and other novel properties. Saproxanthin or myxol might be effective in strengthening biological membranes, reducing permeability to oxygen, and improving protection against oxidation. The antioxidant activity of these two compounds is even higher than zeaxanthin and $\beta$-carotene, which are commonly used antioxidants. Nonetheless, these novel and rare carotenoids require meticulous assessments before their execution in cosmeceutical products [31].

It has been evident that many marine bacteria not only produce several acyclic $\mathrm{C} 30$ carotenoids with a 30-carbon skeleton, but that they also produce dicyclic or monocyclic C40 carotenoids [240,241]. New rare carotenoids with $\beta$-carotene skeleton have been extracted and identified from marine bacteria from the class $\alpha$-proteobacteria, phylum Proteobacteria - carotenoids such as astaxanthin glucoside from Paracoccus sp. strain N81106 [242], 4-ketonostoxanthin 3'-sulfate from Erythrobacter sp. strain. PC6 [243], and 2-hydroxyastaxanthin from Brevundimonas sp. strain SD212 [244]. It is important to mention that these marine bacteria are also capable of producing astaxanthin [245].

\subsection{Exopolysaccharides}

\subsubsection{Exopolysaccharides from Bacteria}

Exopolysaccharides (EPS) comprise a substantial part of dissolved carbon in the marine environment and are effectively engaged in biofilm growth. Different marine bacteria produce EPS based on their ecological niche and physiological demands, and these EPS have important roles such as (a) in adhesion and colonization to surfaces; (b) in protecting cells from extreme temperature, salinity, and osmotic pressure; and (c) in quorum sensing and biochemical interactions [246,247]. These mentioned roles and capabilities offer different advantages even beyond environmental conditions, and these marine bacteria EPS can be extracted, purified, and used in a variety of fields. One remarkable aim is the possible utilization of these ESPs to meet industrial demands [248].

In addition to the various properties reported in research, antioxidant activities have been described as a helping hand of research and industrial development for challenging areas such as cosmetics, pharmacology, and food-processing [31]. Importantly, to understand the renowned structure-function relationship between the reported functions and the associated EPS structural features, deep and detailed structural analysis must be performed. This is remarkably true because tremendously distinct bacterial EPS structures can exhibit "similar" antioxidant activities. In 2016, Wang et al. [249] drew attention to the basic mechanisms for in vitro antioxidant activity of EPS. Bacterial EPS have a chelation activity that is correlated with their antioxidant properties and is linked to their $-\mathrm{OH},-\mathrm{SH},-\mathrm{COOH}$, 
$-\mathrm{PO}_{3} \mathrm{H}_{2},-\mathrm{C}=\mathrm{O},-\mathrm{NR} 2,-\mathrm{S}-$, and $-\mathrm{O}-$ functional groups [250]. Particular side chains, such as $1 \rightarrow 2$, $1 \rightarrow 4$, or $1 \rightarrow 6$, can also control these properties in addition to rhamnose (Rha), fucose (Fuc), or mannan (Man) residues. Low molecular weight EPS exhibit better antioxidant properties due to a higher ratio of reducing terminals, which grants them the ability to better accept and/or eliminate free radicals [251]. We robustly suggest newcomers in the topic to read the comprehensive review of Wang et al. [249].

As we know, several marine bacteria have been reported for their production of antioxidant EPS [252], even if no noteworthy connection has been observed between these properties and the mud, deep-sea hydrothermal vents, or hypersaline marine environments they inhabit. As reported for Pseudomonas stutzeri 273, isolated from marine sediments, it has been recommended that anti-biofilm and anti-biofouling roles are correlated with antioxidant properties [253]. EPS 273, extracted from the aforementioned strain, is rich in glucosamine (GlcN), Rha, glucose (Glc), and Man at 35.4\%, $28.6 \%, 27.2 \%$, and $8.7 \%$, respectively. Another EPS extracted from the marine mud bacterium Bacillus licheniformis exhibits antioxidant activities around $42 \%$ and $51 \%$ for $\mathrm{O}_{2}{ }^{-} \bullet$ and $\bullet \mathrm{OH}$ scavenging, respectively [254]. In the investigation of bacterial antioxidant EPS isolated from Egyptian habitats, EPS from B. licheniformis was reported for its antioxidant properties, which were $97 \%$ against DPPH•. Six other EPS producing marine bacteria with antioxidant properties such as Bacillus insolitus, Bacillus polymyxa, Bacillus marinus, Bacillus anthracis, Staphylococcus sp., and Bacillus brevis were also discovered with $85,84,83,81,81$, and $77 \%$ antioxidant activity against DPPH•, respectively [255]. In 2018, an EPS of $5.50 \times 10^{5}$ Da from Bacillus sp. named MSHN2016, with considerable DPPH• scavenging activity, was extracted and characterized, which was composed of arabinose (Ara), xylose (Xyl), Glc, and glucuronic acid (GlcA) (1:1:2:1 relative ratio) [256]. Shivale et al. (2018) investigated the isolates from 156 EPS-producing bacteria from marine soil in the northwest coastal region of India [257], reporting that the EPS from Bacillus brevis, Bacillus sorensis, Janibacter melonis, and various species of Pseudomonas are an encouraging source of natural antioxidant metabolites. Again in India, an extracted EPS from the marine Microbacterium aurantiacum FSW-25 (named EPSMi-25) was found to have $80 \%$ DPPH• scavenging activity at $1 \mathrm{mg} / \mathrm{mL}$. EPSMi-25 is an acidic sugar that exhibits rheological stability similar to xanthan, and is comprised of Glc, Man, Fuc, and GlcA with a molecular weight of $7 \times 10^{6} \mathrm{Da}$ [258].

Bacteria inhabiting deep-sea environments also produce EPS with antioxidant properties, for example, Zunongwangia profunda SM-A87, which is isolated from a place next to the southern Okinawa Trough at a water depth of $1245 \mathrm{~m}$. SM-A87 EPS show $\mathrm{DPPH} \bullet, \bullet \mathrm{OH}$, and $\mathrm{O}_{2}{ }^{-} \bullet$ scavenging ratios of $48.5,58.7$, and $27.2 \%$, respectively, for concentrations ranging from 0.1 to $10 \mathrm{mg} / \mathrm{mL}$, which can result from their structure principally composed of GlcA and Fuc. The utilization of antioxidant EPS from polar bacteria is less reported, but some researchers have detected attractive structures, such as from the Arctic marine bacterium Polaribacter sp. SM1127 [259]. SM1127 EPS has a molecular weight of 220 $\mathrm{kDa}$ and is comprised of $\mathrm{N}$-acetylglucosamine (GlcNAc), Man, GlcA, Fuc, Glc, and Rha residues, which are connected in a complex way. It exhibits encouraging scavenging ratios $(10 \mathrm{mg} / \mathrm{mL})$ for DPPH•, $\bullet \mathrm{OH}$, and $\mathrm{O}_{2}{ }^{-} \bullet$, with values around $55.40 \%, 52.1 \%$, and $28.2 \%$, respectively. Also, Edwardsiella tarda has been reported to produce $(1,3)$-linked mannan with a molecular weight that ranges from 29 to 70 $\mathrm{kDa}$ [260].

Collectively, Table 4 gives a non-exhaustive overview of some marine bacteria that produce antioxidant EPS reported in the last decade. 
Table 4. Non-exhaustive recent examples of antioxidant exopolysaccharide (EPS)-producing marine bacteria.

\begin{tabular}{|c|c|c|c|c|c|c|c|c|c|c|}
\hline Marine Bacteria & EPS Concentration & $\begin{array}{c}\text { DPPH• } \\
\text { Scavenging }\end{array}$ & $\mathrm{O}_{2}^{-} \bullet$ Scavenging & $\begin{array}{l}\text { Free Radical } \\
\text { Scavenging }\end{array}$ & $\begin{array}{c}\text { Nitric } \\
\text { Oxide } \\
\text { Radical } \\
\text { Scavenging }\end{array}$ & $\begin{array}{c}\text { Ferrous } \\
\text { Ions } \\
\text { Chelation } \\
\text { Capacity }\end{array}$ & $\begin{array}{l}\text { Reduction of } \\
\text { Ferric Ions } \\
\text { Power (1) }\end{array}$ & $\begin{array}{c}\text { Lipid } \\
\text { Peroxidation }\end{array}$ & $\begin{array}{c}\bullet \mathrm{OH} \\
\text { Scavenging }\end{array}$ & Reference \\
\hline Aerococcus uriaeequi & $\begin{array}{l}20-100 \mu \mathrm{g} / \mathrm{mL}\left(\mathrm{O}_{2}^{-} \bullet\right) \\
50-250 \mu \mathrm{g} / \mathrm{mL}(\bullet \mathrm{OH})\end{array}$ & - & $12-85 \%$ & - & - & - & - & - & $20-55 \%$ & [261] \\
\hline $\begin{array}{l}\text { Alteromonas sp. } \\
\text { PRIM-21 }\end{array}$ & $0.25-1.0 \mathrm{mg} / \mathrm{mL}$ & $\mathrm{IC}_{50}=0.61 \mathrm{mg} / \mathrm{mL}$ & $\mathrm{IC}_{50}=0.33 \mathrm{mg} / \mathrm{mL}$ & - & - & - & $\begin{array}{l}7.5-20 \mu g \text { eq. } \\
\text { ascorbic acid }\end{array}$ & - & - & [262] \\
\hline \multirow{3}{*}{$\begin{array}{c}\text { Bacillus } \\
\text { amyloliquefaciens } \\
\text { 3MS } 2017\end{array}$} & $100 \mu \mathrm{g} / \mathrm{mL}$ & $86 \%$ & $61 \%$ & $38 \%$ & $64 \%$ & $64 \%$ & 0.003 & $60 \%$ & $62 \%$ & \multirow{3}{*}{ [263] } \\
\hline & $250 \mu \mathrm{g} / \mathrm{mL}$ & $98 \%$ & $72 \%$ & $43 \%$ & $76 \%$ & $70 \%$ & 0.005 & $69 \%$ & $74 \%$ & \\
\hline & $500 \mu \mathrm{g} / \mathrm{mL}$ & $99 \%$ & $83 \%$ & $47 \%$ & $85 \%$ & $70 \%$ & 0.005 & $75 \%$ & $85 \%$ & \\
\hline Bacillus alvei & $20-100 \mathrm{mg} / \mathrm{mL}$ & $96 \%$ & - & - & - & - & - & - & - & \multirow{6}{*}{ [255] } \\
\hline Bacillus anthracis & $20-100 \mathrm{mg} / \mathrm{mL}$ & $82 \%$ & - & - & - & - & - & - & - & \\
\hline Bacillus brevis & $20-100 \mathrm{mg} / \mathrm{mL}$ & $77 \%$ & - & - & - & - & - & - & - & \\
\hline Bacillus circulans & $20-100 \mathrm{mg} / \mathrm{mL}$ & $98 \%$ & - & - & - & - & - & - & - & \\
\hline Bacillus insolitus & $20-100 \mathrm{mg} / \mathrm{mL}$ & $85 \%$ & - & - & - & - & - & - & - & \\
\hline Bacillus licheniformis & $20-100 \mathrm{mg} / \mathrm{mL}$ & $97 \%$ & - & - & - & - & - & - & - & \\
\hline $\begin{array}{l}\text { Bacillus licheniformis } \\
\text { UD061 }\end{array}$ & $5-250 \mathrm{mg} / \mathrm{L}$ & - & $43 \%$ & - & - & - & 0.35 & - & $51 \%$ & {$[254]$} \\
\hline Bacillus marinus & $20-100 \mathrm{mg} / \mathrm{mL}$ & $83 \%$ & - & - & - & - & - & - & - & \multirow{2}{*}{ [255] } \\
\hline Bacillus polymyxa & $20-100 \mathrm{mg} / \mathrm{mL}$ & $84 \%$ & - & - & - & - & - & - & - & \\
\hline $\begin{array}{l}\text { Bacillus sp. } \\
\text { MSHN2016 }\end{array}$ & $30-200 \mu \mathrm{g} / \mathrm{mL}$ & $\mathrm{EC}_{50}=77 \mu \mathrm{g} / \mathrm{mL}$ & - & - & - & - & - & - & - & {$[256]$} \\
\hline $\begin{array}{c}\text { Bacterium } \\
\text { polaribacter sp. } \\
\text { SM1127 }\end{array}$ & $(0.1)-10.0 \mathrm{mg} / \mathrm{mL}$ & $55 \%$ & $28 \%$ & - & - & - & - & - & $52 \%$ & [259] \\
\hline \multirow{2}{*}{ Edwardsiella tarda } & ETW1: $8 \mathrm{mg} / \mathrm{mL}$ & $88 \%$ & - & - & - & - & - & $79 \%$ & $89 \%$ & \multirow{2}{*}[260]{} \\
\hline & ETW2: $8 \mathrm{mg} / \mathrm{mL}$ & $77 \%$ & - & - & - & - & - & $71 \%$ & $77 \%$ & \\
\hline $\begin{array}{c}\text { Enterobacter sp. } \\
\text { PRIM-26 }\end{array}$ & $0.25-1.0 \mathrm{mg} / \mathrm{mL}$ & $\mathrm{IC}_{50}=0.44 \mathrm{mg} / \mathrm{mL}$ & $\mathrm{IC}_{50}=0.65 \mathrm{mg} / \mathrm{mL}$ & - & - & - & $\begin{array}{l}5-12.5 \mu g \text { eq. } \\
\text { ascorbic acid }\end{array}$ & - & - & [262] \\
\hline Janibacter sp. TKB-1 & $<50 \mu \mathrm{g} / \mathrm{mL}$ & $69 \%$ & - & - & - & - & - & - & - & {$[257]$} \\
\hline $\begin{array}{c}\text { Microbacterium } \\
\text { aurantiacum FSW-25 }\end{array}$ & $0.1-3.5 \mathrm{mg} / \mathrm{mL}$ & $20-80 \%$ & $23-90 \%$ & - & - & - & $0.9-1.7$ & - & $25-90 \%$ & [258] \\
\hline
\end{tabular}


Table 4. Cont.

\begin{tabular}{|c|c|c|c|c|c|c|c|c|c|c|}
\hline Marine Bacteria & EPS Concentration & $\begin{array}{c}\text { DPPH• } \\
\text { Scavenging }\end{array}$ & $\mathrm{O}_{2}^{-} \bullet$ Scavenging & $\begin{array}{l}\text { Free Radical } \\
\text { Scavenging }\end{array}$ & $\begin{array}{c}\text { Nitric } \\
\text { Oxide } \\
\text { Radical } \\
\text { Scavenging }\end{array}$ & $\begin{array}{c}\text { Ferrous } \\
\text { Ions } \\
\text { Chelation } \\
\text { Capacity }\end{array}$ & $\begin{array}{l}\text { Reduction of } \\
\text { Ferric Ions } \\
\text { Power (1) }\end{array}$ & $\begin{array}{l}\text { Lipid } \\
\text { Peroxidation }\end{array}$ & $\begin{array}{c}\bullet \mathrm{OH} \\
\text { Scavenging }\end{array}$ & Reference \\
\hline $\begin{array}{l}\text { Nitratireductor sp. } \\
\text { PRIM-24 }\end{array}$ & $0.25-1.0 \mathrm{mg} / \mathrm{mL}$ & $\mathrm{IC}_{50}=0.49 \mathrm{mg} / \mathrm{mL}$ & none & - & - & - & $\begin{array}{l}\text { 10-24 } \mu \text { g eq. } \\
\text { ascorbic acid }\end{array}$ & - & - & [262] \\
\hline Pseudomonas PF-6 & $0-3 \mathrm{mg} / \mathrm{mL}$ & $\mathrm{IC}_{50}=180 \mu \mathrm{g} / \mathrm{mL}$ & $\mathrm{IC}_{50}=149 \mu \mathrm{g} / \mathrm{mL}$ & - & - & - & $0.2-0.8$ & - & $\begin{array}{c}\mathrm{IC}_{50}=340 \\
\mu \mathrm{g} / \mathrm{mL}\end{array}$ & [264] \\
\hline $\begin{array}{l}\text { Pseudomonas sp. } \\
\text { KKB-1 }\end{array}$ & $<50 \mu \mathrm{g} / \mathrm{mL}$ & $63 \%$ & - & - & - & - & - & - & - & [257] \\
\hline $\begin{array}{c}\text { Pseudomonas stuzeri } \\
273\end{array}$ & $5-20 \mu \mathrm{g} / \mathrm{mL}$ & - & $\mathrm{IC}_{50}=20 \mu \mathrm{g} / \mathrm{mL}$ & - & - & - & - & - & $\begin{array}{c}\mathrm{IC}_{50}=60 \\
\mu \mathrm{g} / \mathrm{mL}\end{array}$ & [253] \\
\hline Staphylococcus sp. & $20-100 \mathrm{mg} / \mathrm{mL}$ & $80 \%$ & - & - & - & - & - & - & - & [255] \\
\hline $\begin{array}{l}\text { Zunongwangia } \\
\text { profunda SM-A87 }\end{array}$ & $(0.1)-10 \mathrm{mg} / \mathrm{mL}$ & $49 \%$ & $27 \%$ & - & - & - & - & - & $59 \%$ & [265] \\
\hline
\end{tabular}

DPPH•: 1,1diphenyl-2-picryl-hydrazyl free radical; \%: corresponds to inhibition \%; ${ }^{(1)}$ In absorbance $\left(\mathrm{A}_{700}\right)$; ETW1 and ETW2: Two water-soluble extracellular polysaccharides derived from Edwardsiella tarda. 


\subsubsection{Exopolysaccharides from Microalgae}

Polysaccharides, and more specifically soluble EPS, which are produced by several prokaryotic and eukaryotic microalgae, are at the center of attention of the academic and industrial communities due to their antioxidant and other novel properties [266,267]. Currently, highly valuable compounds, such as pigments and sulfated polysaccharides for industrial production, are only produced by 10 to 15 microalgae species, whereas other species are still being studied [49,266-269]. In fact, metabolism of aerobic organisms, as well as some exogenous agents, produce ROS such as superoxide radicals $\left(\mathrm{O} 2 \bullet^{-}\right)$, singlet oxygen $\left({ }^{1} \mathrm{O}_{2}\right)$, hydroxyl radicals $(\bullet \mathrm{OH})$, and hydrogen peroxide $\left(\mathrm{H}_{2} \mathrm{O}_{2}\right)$, which are believed to be the origin of some forms of cellular damage such as aging, mutagenesis, and carcinogenesis [270]. Photoautotrophic microalgae collect and store antioxidative scavenger complexes, such as polysaccharides, to protect their cells from long-time exposure to ROS and other free radicals [264]. Many polysaccharides that are derived from these microorganisms have been recognized as probable antioxidants (Table 5) [264,266,267,271]. Glycosidic linkages, monosaccharide composition, molecular weight, and conformation of antioxidant polysaccharides determine their scavenging activity [272]. The ability of ion chelation (uronic acids containing polysaccharides) and radical scavenging reducing power of polysaccharides are the two factors that define their antioxidant properties. It is also proposed that the antioxidant activities of some of these polysaccharides emerge through induction of gene expression of those which encode antioxidant enzymes such as superoxide dismutase or glutathione peroxidase. However, due to lack of available information on molecular mechanisms responsible for antioxidant activities, this property of polysaccharides remains debatable. Furthermore, some non-carbohydrate compounds with antioxidant properties, which are extracted alongside polysaccharides, are occasionally believed to be obstructions for the source of the detected scavenging activities [271]. The isolated antioxidant polysaccharides from prokaryotic microalgae such as Spirulina platensis and Nostoc flagelliforme and eukaryotic microalgae such as Navicula sp., Rhodella reticulata, Porphyridium sp., Porphyridium cruentum, Dunaliella salina, Schizochytrium sp., and Isochrysis galbana have effective scavenging activities on hydroxyl radicals, hydroxyl peroxide, and superoxide radicals [24,273-278]. The absence of appropriately defined structures is an obstacle on the way of polysaccharide application in the fields of food and health, even though in many studies the scavenging abilities of these polysaccharides have been verified. Additionally, commercial antioxidants such as BHA, propyl gallate, BHT, and tertiary butylhydroxyquinone, which are authorized as food antioxidants, show higher antioxidant activities than most of the microalgae-derived polysaccharides [279], a fact that restricts the potential application of the microalgae-derived polysaccharides. Several authors have suggested strategies such as culture condition regulations as a method for the enhancement of antioxidant activities of polysaccharide.

Table 5. Antioxidant assays performed on EPS from microalgae.

\begin{tabular}{|c|c|c|c|}
\hline Microalgae & EPS Composition & $\begin{array}{c}\text { Antioxidant and Scavenging Activity } \\
\text { Determination Assays }\end{array}$ & Reference \\
\hline Navicula sp. & $\begin{array}{l}\text { Glc, Rha, Gal, Man, Xyl, } \\
\text { protein, sulfate }\end{array}$ & DPPH, ABTS radical scavenging assays & [280] \\
\hline Pavlova viridis & N.D.* & $\begin{array}{l}\text { DPPH, LPO, hydroxyl and superoxide } \\
\text { anion radical scavenging assays, mouse } \\
\text { red blood cell hemolysis assay }\end{array}$ & [281] \\
\hline Porphyridium sp. & $\begin{array}{l}\text { Xyl, Glc, Gal, Ara, Rha, } \\
\text { Man, GlcA, sulfates }\end{array}$ & TBA, FOX, and DCFH assays & [24] \\
\hline
\end{tabular}


Table 5. Cont.

\begin{tabular}{|c|c|c|c|}
\hline Microalgae & EPS Composition & $\begin{array}{c}\text { Antioxidant and Scavenging Activity } \\
\text { Determination Assays }\end{array}$ & Reference \\
\hline Porphyridium cruentum & $\begin{array}{l}\text { Xyl, Glc, Gal, GlcA, } \\
\text { sulfates }\end{array}$ & $\begin{array}{l}\text { LPO assay in mouse liver homogenates, } \\
\text { hydroxyl and superoxide anion radical } \\
\text { scavenging assays }\end{array}$ & [96] \\
\hline Rhodella reticulata & $\begin{array}{l}\text { Xyl, Glc, Gal, Rha, GlcA, } \\
\text { sulfates }\end{array}$ & $\begin{array}{l}\text { FOX and TAOC assays, hydroxyl and } \\
\text { superoxide anion radicals scavenging } \\
\text { assays }\end{array}$ & {$[276,282]$} \\
\hline Sarcinochrysis marina & N.D.* & $\begin{array}{l}\text { DPPH, LPO, hydroxyl and superoxide } \\
\text { anion radicals scavenging assays, } \\
\text { mouse red blood cell hemolysis assay }\end{array}$ & [281] \\
\hline
\end{tabular}

The Diatom Navicula sp. produces a sulfated EPS that is composed of Glc, Rha, Xyl, Man, and galactose (Gal) at several ratios on the basis of the wavelengths utilized to cultivate the strain [280], with polysaccharides derived from the white wavelength-irritated cultures having higher Rha and sulfated content, as well as a higher scavenging activity (DPPH•) in comparison to those derived from the red and blue wavelength-irritated cultures, resulting in higher molecular weights. Likewise, three polysaccharides that have been isolated from Nostoc flagelliforme, cultivated in normal, salt stress, and mixotrophic conditions, contain nine different monosaccharides with their uronic acid content, monosaccharide ratio, and molecular weights differing on the basis of the conditions of their culture. The polysaccharides isolated from mixotrophic culture conditions exhibit the highest antioxidant activity, even though all these polysaccharides demonstrate robust scavenging activity on hydroxyl and 2,2'-azino-bis(3-ethylbenzothiazoline-6-sulfonic acid) radicals (ABTS•) [273]. The thing that makes it challenging to accomplish an accepted structural adaptation of EPS to environmental conditions is the lack of complete characterization of polysaccharides to detect real structural differences. On the other hand, they pave the way for new strategies to optimize the antioxidant properties of microalgae-produced EPS.

A mucilage made of partly soluble sulfated polysaccharides, which is sometimes non-covalently linked with glycoproteins, encapsulates the cell of red microalgae [24,267]. These polysaccharide layers increase in size on the basis of physicochemical environmental conditions and nutrient starvation, and can reach up to $50-60 \%$ of dry matter, which supports the idea that under stress conditions, these microalgae supply and utilize energy to synthesize exocellular sugars to survive. Some of the closely studied red microalgae are the strains that belong to the Porphyridium genus [267]. These species naturally inhabit shallow near-shore waters and sea sands, which are accompanied by stress conditions, such as salts, temperature, and light, resulting in ROS formation. Tannin-Spitz et al. (2005) have proven the protective role of the EPS from Porphyridium sp. against oxidation by showing their capability to restrain in vitro autoxidation of linoleic acid, ferrous oxidation, and the oxidative damage to $3 \mathrm{~T} 3$ cells caused by $\mathrm{FeSO}_{4}$ [24]. Furthermore, Sun et al. (2009) verified the scavenging abilities of the polysaccharides from Porphyridium species on free radicals and their inhibitory effects on ascorbic acid- and $\mathrm{FeSO}_{4}$-induced lipid peroxidation in liver homogenates and mouse erythrocyte hemolysis using low molecular weight forms obtained after microwave degradation [96]. It is important to state that these authors did not find substantial antioxidant abilities with the crude high molecular weight polysaccharide fractions. 


\subsection{Others Bioactive Compounds from Marine Bacteria and Microalgae}

\subsubsection{Bioactive Peptides}

Recently, several bioactive peptides have been detected in a variety of marine protein resources that possess antioxidant properties. Because marine bacteria and microalgae are full of proteins but have low amounts of fat, they are known as reliable sources of new antioxidant peptides [283]. Many reports have declared that antioxidant peptides usually have 3-20 amino acid residues [284] and have positive effects on human health, and thus could be used in the food industry. Antioxidant activity of bioactive peptides can result from their free radical scavenging activity, metal ion chelating capability, and lipid peroxidation inhibition [283]. Because of the sequential, structural, and compositional properties of these peptides, besides antioxidant activities [285,286], they might show various kinds of bioactivities such as antihypertensive [287], immunomodulatory effects [288,289], and anticancer and antimicrobial activity [283]. Peptides extracted from marine bacteria and microalgae could be used as food additives to improve consumer health and shelf life of food products [290].

Recently, some algae proteins such as Chlorella vulgaris, Chlorella ellipsoidea, and red algae Palmaria palmata waste proteins have been discovered to be close relative proteins of antioxidant peptides [283]. For example, the peptide Valine-Glutamic acid-Cysteine-Tyrosine-Glycine-Proline-AsparagineArginine-Proline-Glutamine-Phenylalanine, released from pepsin hydrolysate of Chlorella vulgaris, exhibits the greatest ABTS• scavenging activity in comparison to Trolox, ascorbic acid, and BHT [291].

According to investigations regarding the antioxidant activity of foods, it has been found that enzymatic digestion of different marine food proteins, such as Spirulina platensis, Dunaliella salina, Botryococcus braunii, dried bonito, dried salted fish, fish sauce, and fish water-soluble proteins results in the production of several antioxidant peptides [292]. Many human and animal studies have revealed that Chlorella intake gives rise to robust antioxidant potential, possibly resulting from their active peptide content, but we have to state that the mechanism is still undetermined [293]. Hydrolysates and peptides with antioxidant activities from marine bacteria and microalgae can be consumed as food additives to diminish oxidative changes occurring during storage in different food products. They also havve exclusive techno-functional properties, such as low viscosity, high solubility, and resistance to gel formation [290].

\subsubsection{Mycosporine-Like Amino Acid and Scytonemin}

Mycosporine-like amino acids (MAAs) are a family of secondary metabolites with a molecular weight of less than 400 Da. MAAs are colorless, uncharged, and water-soluble ampholytes with similar chemical structures differing in amino acid composition and are produced by bacteria and microalgae living in high sunlight habitats as a response to solar radiation [294]. Both prokaryotic and eukaryotic microalgae can be a source for the extraction of MAAs with the capability to be utilized in sunscreens. Additionally, mycosporine-glycine has great antioxidant, anti-inflammatory, and antiaging activities, as previous research disclosed, which offers a new understanding for the use of MAAs in cosmeceutical fields [31].

Furthermore, other photoprotective compounds such as Scytonemin, which is a dimer of indolic and phenolic subunits capable of decreasing the risk of damages resulted from UV light, have been isolated from prokaryotic microalgae [55].

\subsubsection{Vitamins, Mannosylglycerate, Phycoerythrobilin, and Phycobiliproteins}

Molecules such as polyphenols, fatty acids, tocopherol, flavonoids, alkaloids, polyketides, glycosides, isoprenoids, catalases, and superoxide dismutase, which play key roles in the control of oxidative processes, could be derived from marine bacteria and microalgae [31,74,235]. Vitamin E is believed to be an applicable antioxidant and is commonly used in the formulation of cosmetic products. Because microalgae, such as Dunaliella tertiolecta and Tetraselmis suecica, produce great amounts of $\alpha$-tocopherol and vitamins, they could be valuable vitamin E sources [55]. 
Hyperthermophilic bacteria produce mannosylglycerate (MG), which is a biocompatible solute. In yeast models, MG has inhibitory effects on $\alpha$-synuclein aggregates in Parkinson's disease (PD). It is also considered as a good candidate for the treatment of PD because it can induce proper folding of $\alpha$-synuclein and prevent its pathological aggregation [295].

Phycoerythrobilin, which is a red phycobilin isolated from Spirulina and Porphyridium, exhibits antioxidant properties, and it also could be applied in the decorative cosmetics industry for making products such as eye-liners and lipsticks. Phycobiliproteins isolated from Porphyridium aerogineum, which are light energy capturing protein complexes covalently bound to phycobilins, are also utilized in the food and cosmetic fields as colorants without showing any alterations due to $\mathrm{pH}$ fluctuations (4 to 5) and having color stability under light [55].

\subsubsection{Ovothiols}

Ovothiols are sulfur-containing natural compounds biosynthesized by many marine organisms and microorganisms including microalgae such as Dunaliella salina and Euglena gracilis, as well as many marine bacteria such as Shewanella, Photobacteria, and Pseudoalteromonas. These compounds own unique chemical properties and various cellular functions. They show protective activity against oxidative stress, act as molecular messengers for inter- and intracellular signaling pathways, and serve as building blocks of more complex structures [296-298].

They enable organisms to survive changing environmental conditions and play a crucial role in maintaining cellular redox homeostasis [299,300]. 5-Thiohistidines act as outstanding nucleophiles and reducing agents, providing cellular protection against reactive oxygen and nitrogen species, electrophilic organic compounds, and thiophilic metals [296].

Ovothiol A (5(N $\pi)$-methyl thiohistidine) is one of the most abundant marine sulfur compounds. Due to the unique antioxidant properties [301-303] and broad distribution among marine microorganisms such as microalgae and Proteobacteria, it is believed that ovothiol A and its derivatives, ovothiol B and C, play important roles in cellular biochemistry [304,305].

Studies have demonstrated that some ovothiol derivatives act as neuroprotective agents for the mammalian brain. Furthermore, ovothiol A is believed to be an antioxidant due to its ROS and peroxynitrite scavenging activity and the ability to produce nitric oxide that can modulate endothelium functionality. Therefore, ovothiols may have anti-atherogenic properties and therapeutic potential in pathologies related to cardiovascular diseases caused by oxidative/inflammatory stress and endothelial dysfunction [296].

\section{Conclusions}

So far, among several biosources of marine bioactive compounds (carotenoids and ESP) with antioxidant properties and other biological applications, microalgae have been in the center of interest because of their rapid replicability, ecological sustainability, simplicity of cultivation, and capability of adaptation to changing environmental conditions. It is also worth mentioning that, in many cases, the carotenoid and EPS production yield of microalgae is much higher than marine bacteria, which makes them a more cost-effective option for the biotechnological scale production of the mentioned bioactive compounds. Additionally, modification of cultivation conditions and genetic engineering methods could also play key roles in increasing the production yield of both marine bacteria and microalgae. On the other hand, one other thing that must always be considered is the antioxidant activity and other properties of these bioactive compounds. Even though they might have the same structural, compositional, and sequential properties, microalgae-derived bioactive compounds show a higher bioactivity rate as compared with their marine bacteria-derived counterparts. Furthermore, for other rare bioactive compounds (other than carotenoids and ESP), it is hard and almost impossible to decide between marine bacteria and microalgae as a source for the biotechnological scale production, and because for production of each specific compound, a different type of microorganism might be suitable, 
we purpose that further investigations need to be conducted to determine the best producer for a specific type of bioactive compound.

Author Contributions: Conceptualization, M.H., P.S.K. (Pouya Safarzadeh Kozani), P.S.K. (Pooria Safarzadeh Kozani), and C.D.; investigation, M.H., P.S.K. (Pouya Safarzadeh Kozani), P.S.K. (Pooria Safarzadeh Kozani), G.P., P.M., and C.D.; writing—original draft preparation, M.H., P.S.K. (Pouya Safarzadeh Kozani), P.S.K. (Pooria Safarzadeh Kozani), and C.D.; writing-review and editing, M.H., P.S.K. (Pouya Safarzadeh Kozani), P.S.K. (Pooria Safarzadeh Kozani), and C.D.; visualization, M.H., P.S.K. (Pouya Safarzadeh Kozani), and P.S.K. (Pooria Safarzadeh Kozani); supervision, M.H. and C.D.; project administration, M.H. and C.D.; funding acquisition, C.D. All authors have read and agreed to the published version of the manuscript.

Funding: This research received no external funding.

Conflicts of Interest: The authors declare no conflict of interest.

\section{References}

1. Fang, Y.Z.; Yang, S.; Wu, G. Free radicals, antioxidants, and nutrition. Nutrition 2002, 18, 872-879. [CrossRef]

2. Martinez-Cayuela, M. Oxygen free radicals and human disease. Biochimie 1995, 77, 147-161. [CrossRef]

3. Schieber, M.; Chandel, N.S. ROS function in redox signaling and oxidative stress. Curr. Biol. 2014, 24, R453-R462. [CrossRef] [PubMed]

4. Halliwell, B. Reactive oxygen species in living systems: Source, biochemistry, and role in human disease. Am. J. Med. 1991, 91, S14-S22. [CrossRef]

5. Cuzzocrea, S.; Riley, D.P.; Caputi, A.P.; Salvemini, D. Antioxidant therapy: A new pharmacological approach in shock, inflammation, and ischemia/reperfusion injury. Pharmacol. Rev. 2001, 53, 135-159. [PubMed]

6. Iverson, F. Phenolic antioxidants: Health protection branch studies on butylated hydroxyanisole. Cancer Lett. 1995, 93, 49-54. [CrossRef]

7. Harrison, D.; Griendling, K.K.; Landmesser, U.; Hornig, B.; Drexler, H. Role of oxidative stress in atherosclerosis. Am. J. Cardiol. 2003, 91, 7-11. [CrossRef]

8. Ostrakhovitch, E.A.; Afanas'ev, I.B. Oxidative stress in rheumatoid arthritis leukocytes: Suppression by rutin and other antioxidants and chelators. Biochem. Pharmacol. 2001, 62, 743-746. [CrossRef]

9. Ceriello, A.; Motz, E. Is oxidative stress the pathogenic mechanism underlying insulin resistance, diabetes, and cardiovascular disease? The common soil hypothesis revisited. Atertio. Thromb. Vasc. Biol. 2004, 24, 816-823. [CrossRef]

10. Finkel, T. Signal transduction by reactive oxygen species. J. Cell Biol. 2011, 194, 7-15. [CrossRef]

11. Hensley, K.; Robinson, K.A.; Gabbita, S.P.; Salsman, S.; Floyd, R.A. Reactive oxygen species, cell signaling, and cell injury. Free Radic. Biol. Med. 2000, 28, 1456-1462. [CrossRef]

12. Waris, G.; Ahsan, H. Reactive oxygen species: Role in the development of cancer and various chronic conditions. J. Carcinog. 2006, 5, 14. [CrossRef] [PubMed]

13. Qi, H.; Zhang, Q.; Zhao, T.; Chen, R.; Zhang, H.; Niu, X.; Li, Z. Antioxidant activity of different sulfate content derivatives of polysaccharide extracted from Ulva pertusa (Chlorophyta) in vitro. Int. J. Biol. Macromol. 2005, 37, 195-199. [CrossRef] [PubMed]

14. Redouan, E.; Emmanuel, P.; Michelle, P.; Bernard, C.; Josiane, C.; Cédric, D. Evaluation of antioxidant capacity of ulvan-like polymer obtained by regioselective oxidation of gellan exopolysaccharide. Food Chem. 2011, 127, 976-983. [CrossRef]

15. Delattre, C.; Fenoradosoa, T.A.; Michaud, P. Galactans: An overview of their most important sourcing and applications as natural polysaccharides. Braz. Arch. Biol. Technol. 2011, 54, 1075-1092. [CrossRef]

16. Yen, G.C.; Duh, P.D.; Tsai, C.L. Relationship between antioxidant activity and maturity of peanut hulls. J. Agric. Food Chem. 1993, 41, 67-70. [CrossRef]

17. Duh, P.-D. Antioxidant activity of water extract of four Harng Jyur (Chrysanthemum morifolium Ramat) varieties in soybean oil emulsion. Food Chem. 1999, 66, 471-476. [CrossRef]

18. Bouissil, S.; Pierre, G.; El Alaoui-Talibi, Z.; Michaud, P.; El Modafar, C.; Delattre, C. Applications of Algal Polysaccharides and Derivatives in Therapeutic and Agricultural Fields. Curr. Pharm. Des. 2019, 25, 1187-1199. [CrossRef]

19. Olszowy, M. What is responsible for antioxidant properties of polyphenolic compounds from plants? Plant Physiol. Biochem. 2019, 144, 135-143. [CrossRef] 
20. Veskoukis, A.; Kerasioti, E.; Priftis, A.; Kouka, P.; Spanidis, Y.; Makri, S.; Kouretas, D. A battery of translational biomarkers for the assessment of the in vitro and in vivo antioxidant action of plant polyphenolic compounds: The biomarker issue. Curr. Opin. Toxicol. 2019, 13, 99-109. [CrossRef]

21. Hentati, F.; Delattre, C.; Ursu, A.V.; Desbrières, J.; Le Cerf, D.; Gardarin, C.; Abdelkafi, S.; Michaud, P.; Pierre, G. Structural characterization and antioxidant activity of water-soluble polysaccharides from the Tunisian brown seaweed Cystoseira Compressa. Carbohydr. Polym. 2018, 198, 589-600. [CrossRef] [PubMed]

22. Khajouei, R.A.; Keramat, J.; Hamdami, N.; Ursu, A.-V.; Delattre, C.; Laroche, C.; Gardarin, C.; Lecerf, D.; Desbrières, J.; Djelveh, G. Extraction and characterization of an alginate from the Iranian brown seaweed Nizimuddinia zanardini. Int. J. Biol. Macromol. 2018, 118, 1073-1081. [CrossRef] [PubMed]

23. Ngo, D.-H.; Kim, S.-K. Sulfated polysaccharides as bioactive agents from marine algae. Int. J. Biol. Macromol. 2013, 62, 70-75. [CrossRef] [PubMed]

24. Tannin-Spitz, T.; Bergman, M.; van-Moppes, D.; Grossman, S.; Arad, S.M. Antioxidant activity of the polysaccharide of the red microalga Porphyridium sp. J. Appl. Phycol. 2005, 17, 215-222. [CrossRef]

25. Sun, L.; Wang, C.; Shi, Q.; Ma, C. Preparation of different molecular weight polysaccharides from Porphyridium cruentum and their antioxidant activities. Int. J. Biol. Macromol. 2009, 45, 42-47. [CrossRef] [PubMed]

26. Raposo, M.F.d.J.; De Morais, R.M.S.C.; de Morais, B.; Miranda, A.M. Bioactivity and applications of sulphated polysaccharides from marine microalgae. Mar. Drugs 2013, 11, 233-252. [CrossRef] [PubMed]

27. Gong, M.; Bassi, A. Carotenoids from microalgae: A review of recent developments. Biotech. Adv. 2016, 34, 1396-1412. [CrossRef]

28. Sathasivam, R.; Radhakrishnan, R.; Hashem, A.; Abd_Allah, E.F. Microalgae metabolites: A rich source for food and medicine. Saudi J. Biol. Sci. 2017, 26, 709-722. [CrossRef]

29. Brasil, B.d.S.A.F.; de Siqueira, F.G.; Salum, T.F.C.; Zanette, C.M.; Spier, M.R. Microalgae and cyanobacteria as enzyme biofactories. Algal Res. 2017, 25, 76-89. [CrossRef]

30. Baharum, S.N.; Beng, E.; Mokhtar, M. Marine microorganisms: Potential application and challenges. J. Biol. Sci. 2010, 10, 555-564. [CrossRef]

31. Corinaldesi, C.; Barone, G.; Marcellini, F.; Dell'Anno, A.; Danovaro, R. Marine microbial-derived molecules and their potential use in cosmeceutical and cosmetic products. Mar. Drugs 2017, 15, 118. [CrossRef] [PubMed]

32. Siddharth, S.; Vittal, R. Evaluation of Antimicrobial, Enzyme Inhibitory, Antioxidant and Cytotoxic Activities of Partially Purified Volatile Metabolites of Marine Streptomyces sp. S2A. Microorganisms 2018, 6, 72. [CrossRef] [PubMed]

33. Park, E.J.; Pezzuto, J. Antioxidant marine products in cancer chemoprevention. Antioxid. Redox Signal. 2013, 19, 115-138. [CrossRef] [PubMed]

34. Horta, A.; Pinteus, S.; Alves, C.; Fino, N.; Silva, J.; Fernandez, S.; Rodrigues, A.; Pedrosa, R. Antioxidant and antimicrobial potential of the Bifurcaria bifurcata epiphytic bacteria. Mar. Drugs 2014, 12, 1676-1689. [CrossRef]

35. Pawar, R.; Mohandass, C.; Sivaperumal, E.; Sabu, E.; Rajasabapathy, R.; Jagtap, T. Epiphytic marine pigmented bacteria: A prospective source of natural antioxidants. Braz. J. Microbiol. 2015, 46, 29-39. [CrossRef]

36. Rao, T.E.; Imchen, M.; Kumavath, R. Marine enzymes: Production and applications for human health. Adv. Food Nutr. Res. 2017, 80, 149-163. [CrossRef]

37. Hamidi, M.; Hejazi, M.S.; Nazemyieh, H.; Hejazi, M.A.; Naziri, D.J.P. Halorubrum sp. TBZ112, an Extremely Halophilic Carotenoid-Producing Archaeon Isolated from Urmia Lake. Pharm. Sci. 2017, 23. [CrossRef]

38. Naziri, D.; Hamidi, M.; Hassanzadeh, S.; Tarhriz, V.; Zanjani, B.M.; Nazemyieh, H.; Hejazi, M.A.; Hejazi, M.S. Analysis of carotenoid production by Halorubrum sp. TBZ126; an extremely halophilic archeon from Urmia Lake. Adv. Pharm. Bull. 2014, 4, 61. [CrossRef]

39. Rodrigo-Baños, M.; Garbayo, I.; Vílchez, C.; Bonete, M.; Martínez-Espinosa, R. Carotenoids from Haloarchaea and their potential in biotechnology. Mar. Drugs 2015, 13, 5508-5532. [CrossRef]

40. Zalazar, L.; Pagola, P.; Miró, M.; Churio, M.; Cerletti, M.; Martínez, C.; Iniesta-Cuerda, M.; Soler, A.; Cesari, A.; De Castro, R. Bacterioruberin extracts from a genetically modified hyperpigmented Haloferax volcanii strain: Antioxidant activity and bioactive properties on sperm cells. J. Appl. Microbiol. 2019, 126, 796-810. [CrossRef]

41. Torregrosa-Crespo, J.; Montero, Z.; Fuentes, J.; Reig García-Galbis, M.; Garbayo, I.; Vílchez, C.; Martínez-Espinosa, R.J.M.d. Exploring the valuable carotenoids for the large-scale production by marine microorganisms. Mar. Drugs 2018, 16, 203. [CrossRef] [PubMed] 
42. Hou, J.; Cui, H.L. In Vitro Antioxidant, Antihemolytic, and Anticancer Activity of the Carotenoids from Halophilic Archaea. Curr. Microbiol. 2018, 75, 266-271. [CrossRef] [PubMed]

43. De la Vega, M.; Sayago, A.; Ariza, J.; Barneto, A.G.; León, R.J.B.P. Characterization of a bacterioruberin-producing Haloarchaea isolated from the marshlands of the Odiel river in the southwest of Spain. Biotechnol. Prog. 2016, 32, 592-600. [CrossRef] [PubMed]

44. Abbes, M.; Baati, H.; Guermazi, S.; Messina, C.; Santulli, A.; Gharsallah, N.; Ammar, E. Biological properties of carotenoids extracted from Halobacterium halobium isolated from a Tunisian solar saltern. BMC Complement. Altern. Med. 2013, 13, 255. [CrossRef]

45. Mandelli, F.; Miranda, V.S.; Rodrigues, E.; Mercadante, A.Z. Biotechnology Identification of carotenoids with high antioxidant capacity produced by extremophile microorganisms. World. J. Microbiol. Biotechnol. 2012, 28, 1781-1790. [CrossRef]

46. Tesson, S.V.; Skjøth, C.A.; Šantl-Temkiv, T.; Löndahl, J. Airborne microalgae: Insights, opportunities, and challenges. Appl. Environ. Microbiol. 2016, 82, 1978-1991. [CrossRef]

47. Rajvanshi, S.; Sharma, M.P. Micro algae: A potential source of biodiesel. J. Sustain. Bioenergy Syst. $2012,2,49$. [CrossRef]

48. Williams, P.J.1.B.; Laurens, L.M. Microalgae as biodiesel \& biomass feedstocks: Review \& analysis of the biochemistry, energetics \& economics. Energy Environ. Sci. 2010, 3, 554-590. [CrossRef]

49. Idrees, M. Making biofuels from microalgae-A review of technologies. J. Food Sci. Technol. 2014, 1, 7-14.

50. Romano, G.; Costantini, M.; Sansone, C.; Lauritano, C.; Ruocco, N.; Ianora, A. Marine microorganisms as a promising and sustainable source of bioactive molecules. Mar. Environ. Res. 2017, 128, 58-69. [CrossRef]

51. Norton, T.A.; Melkonian, M.; Andersen, R.A. Algal biodiversity. Phycologia 1996, 35, 308-326. [CrossRef]

52. Richmond, A. Handbook of Microalgal Culture: Biotechnology and Applied Phycology; Wiley-Blackwell: Oxford, UK, 2004; Volume 577.

53. Guiry, M.D. How many species of algae are there? J. Phycol. 2012, 48, 1057-1063. [CrossRef] [PubMed]

54. Chen, P.; Min, M.; Chen, Y.; Wang, L.; Li, Y.; Chen, Q.; Wang, C.; Wan, Y.; Wang, X.; Cheng, Y. Review of biological and engineering aspects of algae to fuels approach. Int. J. Agric. Biol. Eng. 2010, 2, 1-30. [CrossRef]

55. Mourelle, M.; Gómez, C.; Legido, J. The potential use of marine microalgae and cyanobacteria in cosmetics and thalassotherapy. Cosmetics 2017, 4, 46. [CrossRef]

56. Ibañez, E.; Cifuentes, A. Benefits of using algae as natural sources of functional ingredients. J. Sci. Food Agric. 2013, 93, 703-709. [CrossRef] [PubMed]

57. Abdel-Raouf, N.; Al-Homaidan, A.; Ibraheem, I. Microalgae and wastewater treatment. Saudi J. Biol. Sci. 2012, 19, 257-275. [CrossRef]

58. Shalaby, E.A. Algae as promising organisms for environment and health. Plant Signal Behav. 2011, 6, 1338-1350. [CrossRef]

59. Ejike, C.E.; Collins, S.A.; Balasuriya, N.; Swanson, A.K.; Mason, B.; Udenigwe, C.C. Prospects of microalgae proteins in producing peptide-based functional foods for promoting cardiovascular health. Trends Food Sci. Technol. 2017, 59, 30-36. [CrossRef]

60. Khan, M.I.; Shin, J.H.; Kim, J.D. The promising future of microalgae: Current status, challenges, and optimization of a sustainable and renewable industry for biofuels, feed, and other products. Microb. Cell Fact. 2018, 17, 36. [CrossRef]

61. Becker, W. Microalgae in human and animal nutrition. In Handbook of Microalgal Culture: Biotechnology and Applied Phycology; Wiley-Blackwell: Oxford, UK, 2004; Volume 312. [CrossRef]

62. Yamaguchi, K. Recent advances in microalgal bioscience in Japan, with special reference to utilization of biomass and metabolites: A review. J. Appl. Phycol. 1996, 8, 487-502. [CrossRef]

63. Garlapati, D.; Chandrasekaran, M.; Devanesan, A.; Mathimani, T.; Pugazhendhi, A. Biotechnology Role of cyanobacteria in agricultural and industrial sectors: An outlook on economically important byproducts. Appl. Microbiol. Biotechnol. 2019, 1-13. [CrossRef]

64. Deng, R.; Chow, T. Hypolipidemic, antioxidant, and antiinflammatory activities of microalgae Spirulina. Cardiovasc. Ther. 2010, 28, e33-e45. [CrossRef] [PubMed]

65. Vonshak, A. Spirulina Platensis Arthrospira: Physiology, Cell-Biology and Biotechnology; Taylor \& Francis Group: London, UK, 1997.

66. Gershwin, M.E.; Belay, A. Spirulina in Human Nutrition and Health; Taylor \& Francis Group: Boca Raton, FL, USA, 2007. 
67. Khan, Z.; Bhadouria, P.; Bisen, P. Nutritional and therapeutic potential of Spirulina. Curr. Pharm. Biotechnol. 2005, 6, 373-379. [CrossRef]

68. Karkos, P.; Leong, S.; Karkos, C.; Sivaji, N.; Assimakopoulos, D. Spirulina in clinical practice: Evidence-based human applications. Evid. Based. Complement. Alternat. Med. 2008, 2011, 27. [CrossRef]

69. Spolaore, P.; Joannis-Cassan, C.; Duran, E.; Isambert, A. Commercial applications of microalgae. J. Biosci. Bioeng. 2006, 101, 87-96. [CrossRef]

70. Cardozo, K.H.; Guaratini, T.; Barros, M.P.; Falcão, V.R.; Tonon, A.P.; Lopes, N.P.; Campos, S.; Torres, M.A.; Souza, A.O.; Colepicolo, P.; et al. Metabolites from algae with economical impact. Comp. Biochem. Physiol. C. Toxicol. Pharmacol. 2007, 146, 60-78. [CrossRef]

71. Batista, A.P.; Gouveia, L.; Bandarra, N.M.; Franco, J.M.; Raymundo, A. Comparison of microalgal biomass profiles as novel functional ingredient for food products. Algal Res. 2013, 2, 164-173. [CrossRef]

72. Fajardo, C.; De Donato, M.; Carrasco, R.; Martínez-Rodríguez, G.; Mancera, J.M.; Fernández-Acero, F.J. Advances and challenges in genetic engineering of microalgae. Rev. Aquacult. 2019. [CrossRef]

73. Sansone, C.; Brunet, C. Promises and Challenges of Microalgal Antioxidant Production. Antioxidants 2019, 8, 199. [CrossRef]

74. Priyadarshani, I.; Rath, B. Commercial and industrial applications of micro algae-A review. J. Algal Biomass Utln. 2012, 3, 89-100.

75. Liu, L.; Pohnert, G.; Wei, D. Extracellular metabolites from industrial microalgae and their biotechnological potential. Mar. Drugs 2016, 14, 191. [CrossRef] [PubMed]

76. Guedes, A.C.; Gião, M.S.; Seabra, R.; Ferreira, A.C.S.; Tamagnini, P.; Moradas-Ferreira, P.; Malcata, F.X. Evaluation of the Antioxidant Activity of Cell Extracts from Microalgae. Mar. Drugs 2013, 11, 1256-1270. [CrossRef] [PubMed]

77. Mutanda, T.; Ramesh, D.; Karthikeyan, S.; Kumari, S.; Anandraj, A.; Bux, F. Bioprospecting for hyper-lipid producing microalgal strains for sustainable biofuel production. Bioresour. Technol. 2011, 102, 57-70. [CrossRef] [PubMed]

78. Seckbach, J. Algae and Cyanobacteria in Extreme Environments; Springer: Dordrecht, The Netherlands, 2007; Volume 11.

79. Poli, A.; Anzelmo, G.; Nicolaus, B. Bacterial exopolysaccharides from extreme marine habitats: Production, characterization and biological activities. Mar. Drugs 2010, 8, 1779-1802. [CrossRef]

80. Zakaria, S.M.; Kamal, S.M.M.; Harun, M.R.; Omar, R.; Siajam, S.I. Subcritical water technology for extraction of phenolic compounds from Chlorella sp. microalgae and assessment on its antioxidant activity. Molecules 2017, 22, 1105. [CrossRef]

81. Takaichi, S. Carotenoids in algae: Distributions, biosyntheses and functions. Mar. Drugs 2011, 9, 1101-1118. [CrossRef]

82. Jong-Yuh, C.; Mei-Fen, S. Potential hypoglycemic effects of Chlorella in streptozotocin-induced diabetic mice. Life Sci. 2005, 77, 980-990. [CrossRef]

83. Gouveia, L.; Veloso, V.; Reis, A.; Fernandes, H.; Novais, J.; Empis, J. Evolution of pigment composition in Chlorella vulgaris. Bioresour. Technol. 1996, 57, 157-163. [CrossRef]

84. Metting, F. Biodiversity and application of microalgae. J. Ind. Microbiol. 1996, 17, 477-489. [CrossRef]

85. Shah, M.; Mahfuzur, R.; Liang, Y.; Cheng, J.J.; Daroch, M. Astaxanthin-producing green microalga Haematococcus pluvialis: From single cell to high value commercial products. Front. Plant Sci. 2016, 7, 531. [CrossRef]

86. Waldenstedt, L.; Inborr, J.; Hansson, I.; Elwinger, K. Effects of astaxanthin-rich algal meal (Haematococcus pluvalis) on growth performance, caecal campylobacter and clostridial counts and tissue astaxanthin concentration of broiler chickens. Anim. Feed Sci. Technol. 2003, 108, 119-132. [CrossRef]

87. Vílchez, C.; Forján, E.; Cuaresma, M.; Bédmar, F.; Garbayo, I.; Vega, J.M. Marine carotenoids: Biological functions and commercial applications. Mar. Drugs 2011, 9, 319-333. [CrossRef] [PubMed]

88. Miyashita, K. Marine antioxidants: Polyphenols and carotenoids from algae. In Antioxidants and Functional Components in Aquatic Foods; Wiley Online Library: West Sussex, UK, 2014; pp. 219-229.

89. Petruk, G.; Roxo, M.; De Lise, F.; Mensitieri, F.; Notomista, E.; Wink, M.; Izzo, V.; Monti, D.M. The marine Gram-negative bacterium Novosphingobium sp. PP1Y as a potential source of novel metabolites with antioxidant activity. Biotechnol. Lett. 2019, 41, 273-281. [CrossRef] [PubMed]

90. Stolz, P. Manufacturing microalgae for skin care. Cosmet. Toiletries 2005, 120, 99-106. 
91. Guillerme, J.-B.; Couteau, C.; Coiffard, L.J.C. Applications for marine resources in cosmetics. Cosmetics 2017, 4, 35. [CrossRef]

92. Wijffels, R.H. Potential of sponges and microalgae for marine biotechnology. Trends Biotechnol. 2008, 26, 26-31. [CrossRef]

93. Fasano, E.; Serini, S.; Mondella, N.; Trombino, S.; Celleno, L.; Lanza, P.; Cittadini, A.; Calviello, G. Antioxidant and anti-inflammatory effects of selected two human immortalized keratinocyte lines. Biomed. Res. Int. 2014, 2014, 327452. [CrossRef]

94. Li, J.; Zhu, D.; Niu, J.; Shen, S.; Wang, G. An economic assessment of astaxanthin production by large scale cultivation of Haematococcus pluvialis. Biotechnol. Adv. 2011, 29, 568-574. [CrossRef]

95. Park, J.S.; Chyun, J.H.; Kim, Y.K.; Line, L.L.; Chew, B.P. Astaxanthin decreased oxidative stress and inflammation and enhanced immune response in humans. Nutr. Metab. 2010, 7, 18. [CrossRef]

96. Palozza, P.; Torelli, C.; Boninsegna, A.; Simone, R.; Catalano, A.; Mele, M.C.; Picci, N. Growth-inhibitory effects of the astaxanthin-rich alga Haematococcus pluvialis in human colon cancer cells. Cancer Lett. 2009, 283, 108-117. [CrossRef]

97. Sasaki, Y.; Kobara, N.; Higashino, S.; Giddings, J.C.; Yamamoto, J. Astaxanthin inhibits thrombosis in cerebral vessels of stroke-prone spontaneously hypertensive rats. Nutr. Res. 2011, 31, 784-789. [CrossRef] [PubMed]

98. Obulesu, M.; Dowlathabad, M.R.; Bramhachari, P. Carotenoids and Alzheimer's disease: An insight into therapeutic role of retinoids in animal models. Neurochem. Int. 2011, 59, 535-541. [CrossRef] [PubMed]

99. Hussein, G.; Sankawa, U.; Goto, H.; Matsumoto, K.; Watanabe, H. Astaxanthin, a carotenoid with potential in human health and nutrition. J. Nat. Prod. 2006, 69, 443-449. [CrossRef] [PubMed]

100. Hussein, G.; Nakamura, M.; Zhao, Q.; Iguchi, T.; Goto, H.; Sankawa, U.; Watanabe, H. Antihypertensive and neuroprotective effects of astaxanthin in experimental animals. Biol. Pharm. Bull. 2005, 28, 47-52. [CrossRef] [PubMed]

101. Ryu, S.K.; King, T.J.; Fujioka, K.; Pattison, J.; Pashkow, F.J.; Tsimikas, S. Effect of an oral astaxanthin prodrug (CDX-085) on lipoprotein levels and progression of atherosclerosis in $\mathrm{LDLR}^{-/}$and ApoE ${ }^{-/-}$mice. Atherosclerosis 2012, 222, 99-105. [CrossRef]

102. Naito, Y.; Uchiyama, K.; Aoi, W.; Hasegawa, G.; Nakamura, N.; Yoshida, N.; Maoka, T.; Takahashi, J.; Yoshikawa, T. Prevention of diabetic nephropathy by treatment with astaxanthin in diabetic $\mathrm{db} / \mathrm{db}$ mice. BioFactors 2004, 20, 49-59. [CrossRef]

103. Marin, D.P.; Bolin, A.P.; Macedo, R.d.C.S.; Sampaio, S.C.; Otton, R. ROS production in neutrophils from alloxan-induced diabetic rats treated in vivo with astaxanthin. Int. Immunopharmacol. 2011, 11, 103-109. [CrossRef]

104. Comhaire, F.; Garem, Y.E.; Mahmoud, A.; Eertmans, F.; Schoonjans, F. Combined conventional/antioxidant "Astaxanthin" treatment for male infertility: A double blind, randomized trial. Asian J. Androl. 2005, 7, 257-262. [CrossRef]

105. Kim, S.-H.; Jean, D.-I.; Lim, Y.-P.; Lee, C.; An, G. Weight gain limitation and liver protection by long-term feeding of astaxanthin in murines. J. Korean Soc. Appl. Biol. Chem. 2009, 52, 180-185. [CrossRef]

106. Pulz, O.; Gross, W. Valuable products from biotechnology of microalgae. Appl. Microbiol. Biotechnol. 2004, 65, 635-648. [CrossRef]

107. Breithaupt, D. Modern application of xanthophylls in animal feeding-A review. Trends Food Sci. Technol. 2007, 18, 501-506. [CrossRef]

108. Cha, K.H.; Koo, S.Y.; Lee, D.-U. Antiproliferative effects of carotenoids extracted from Chlorella ellipsoidea and Chlorella vulgaris on human colon cancer cells. J. Agric. Food Chem. 2008, 56, 10521-10526. [CrossRef] [PubMed]

109. VijayaPadma, V.; Ramyaa, P.; Pavithra, D.; Krishnasamy, R. Protective effect of lutein against benzo (a) pyrene-induced oxidative stress in human erythrocytes. Toxicol. Ind. Health 2014, 30, 284-293. [CrossRef] [PubMed]

110. Li, S.-Y.; Fung, F.K.; Fu, Z.J.; Wong, D.; Chan, H.H.; Lo, A.C. Anti-inflammatory effects of lutein in retinal ischemic/hypoxic injury: In vivo and in vitro studies. Investig. Ophthalmol. Vis. Sci. 2012, 53, 5976-5984. [CrossRef]

111. Renzi, L.M.; Johnson, E.J. Lutein and age-related ocular disorders in the older adult: A review. J. Nutr. Elder. 2008, 26, 139-157. [CrossRef] 
112. Ma, L.; Lin, X.M. Effects of lutein and zeaxanthin on aspects of eye health. J. Sci. Food Agric. 2010, 90, 2-12. [CrossRef]

113. Dagnelie, G.; Zorge, I.S.; McDonald, T.M. Lutein improves visual function in some patients with retinal degeneration: A pilot study via the Internet. Optometry (St. Louis MO) 2000, 71, 147-164.

114. Aleman, T.S.; Duncan, J.L.; Bieber, M.L.; De Castro, E.; Marks, D.A.; Gardner, L.M.; Steinberg, J.D.; Cideciyan, A.V.; Maguire, M.G.; Jacobson, S.G. Macular pigment and lutein supplementation in retinitis pigmentosa and Usher syndrome. Investig. Ophthalmol. Vis. Sci. 2001, 42, 1873-1881.

115. Bahrami, H.; Melia, M.; Dagnelie, G. Lutein supplementation in retinitis pigmentosa: PC-based vision assessment in a randomized double-masked placebo-controlled clinical trial [NCT00029289]. BMC Ophthalmol. 2006, 6, 23. [CrossRef]

116. Ozawa, Y.; Sasaki, M.; Takahashi, N.; Kamoshita, M.; Miyake, S.; Tsubota, K. Neuroprotective effects of lutein in the retina. Curr. Pharm. Des. 2012, 18, 51-56. [CrossRef]

117. Alves-Rodrigues, A.; Shao, A. The science behind lutein. Toxicol. Lett. 2004, 150, 57-83. [CrossRef] [PubMed]

118. Ciccone, M.M.; Cortese, F.; Gesualdo, M.; Carbonara, S.; Zito, A.; Ricci, G.; De Pascalis, F.; Scicchitano, P.; Riccioni, G. Dietary intake of carotenoids and their antioxidant and anti-inflammatory effects in cardiovascular care. Mediators Inflamm. 2013, 2013, 782137. [CrossRef]

119. Dwyer, J.H.; Navab, M.; Dwyer, K.M.; Hassan, K.; Sun, P.; Shircore, A.; Hama-Levy, S.; Hough, G.; Wang, X.; Drake, T. Oxygenated carotenoid lutein and progression of early atherosclerosis: The Los Angeles atherosclerosis study. Circulation 2001, 103, 2922-2927. [CrossRef] [PubMed]

120. Molnár, P.; Deli, J.; Tanaka, T.; Kann, Y.; Tani, S.; Gyémánt, N.; Molnár, J.; Kawase, M. Carotenoids with anti-Helicobacter pylori activity from Golden delicious apple. Phytother. Res. 2010, 24, 644-648. [CrossRef]

121. Manayi, A.; Abdollahi, M.; Raman, T.; Nabavi, S.F.; Habtemariam, S.; Daglia, M.; Nabavi, S.M. Lutein and cataract: From bench to bedside. Crit. Rev. Biotechnol. 2016, 36, 829-839. [CrossRef]

122. Granado, F.; Olmedilla, B.; Blanco, I. Nutritional and clinical relevance of lutein in human health. Br. J. Nutr. 2003, 90, 487-502. [CrossRef]

123. Bone, R.A.; Landrum, J.T.; Guerra, L.H.; Ruiz, C.A. Lutein and zeaxanthin dietary supplements raise macular pigment density and serum concentrations of these carotenoids in humans. J. Nutr. 2003, 133, 992-998. [CrossRef]

124. Virtamo, J.; Taylor, P.R.; Kontto, J.; Männistö, S.; Utriainen, M.; Weinstein, S.J.; Huttunen, J.; Albanes, D. Effects of $\alpha$-tocopherol and $\beta$-carotene supplementation on cancer incidence and mortality: 18-Year postintervention follow-up of the Alpha-Tocopherol, Beta-Carotene Cancer Prevention Study. Int. J. Cancer 2014, 135, 178-185. [CrossRef]

125. Shaish, A.; Harari, A.; Hananshvili, L.; Cohen, H.; Bitzur, R.; Luvish, T.; Ulman, E.; Golan, M.; Ben-Amotz, A.; Gavish, D. 9-cis $\beta$-carotene-rich powder of the alga Dunaliella bardawil increases plasma HDL-cholesterol in fibrate-treated patients. Atherosclerosis 2006, 189, 215-221. [CrossRef]

126. García-González, M.; Moreno, J.; Manzano, J.C.; Florencio, F.J.; Guerrero, M.G. Production of Dunaliella salina biomass rich in 9-cis- $\beta$-carotene and lutein in a closed tubular photobioreactor. J. Biotechnol. 2005, 115, 81-90. [CrossRef]

127. Graham, R.D.; Rosser, J.M. Carotenoids in staple foods: Their potential to improve human nutrition. Food Nutr. Bull. 2000, 21, 404-409. [CrossRef]

128. Dufossé, L.; Galaup, P.; Yaron, A.; Arad, S.M.; Blanc, P.; Murthy, K.N.C.; Ravishankar, G.A. Microorganisms and microalgae as sources of pigments for food use: A scientific oddity or an industrial reality? Trends Food Sci. Technol. 2005, 16, 389-406. [CrossRef]

129. Etminan, M.; Gill, S.S.; Samii, A. Intake of vitamin E, vitamin C, and carotenoids and the risk of Parkinson's disease: A meta-analysis. Lancet Neurol. 2005, 4, 362-365. [CrossRef]

130. Sies, H.; Stahl, W. Nutritional protection against skin damage from sunlight. Annu. Rev. Nutr. 2004, 24, 173-200. [CrossRef] [PubMed]

131. Aust, O.; Stahl, W.; Sies, H.; Tronnier, H.; Heinrich, U. Supplementation with tomato-based products increases lycopene, phytofluene, and phytoene levels in human serum and protects against UV-light-induced erythema. Int. J. Vitam. Nutr. Res. 2005, 75, 54-60. [CrossRef]

132. Wertz, K.; Hunziker, P.B.; Seifert, N.; Riss, G.; Neeb, M.; Steiner, G.; Hunziker, W.; Goralczyk, R. $\beta$-carotene interferes with ultraviolet light A-induced gene expression by multiple pathways. J. Invest. Dermatol. 2005, 124, 428-434. [CrossRef] 
133. Sesso, H.D.; Buring, J.E.; Norkus, E.P.; Gaziano, J.M. Plasma lycopene, other carotenoids, and retinol and the risk of cardiovascular disease in men. Am. J. Clin. Nutr. 2005, 81, 990-997. [CrossRef]

134. Lidebjer, C.; Leanderson, P.; Ernerudh, J.; Jonasson, L. Low plasma levels of oxygenated carotenoids in patients with coronary artery disease. Nutr. Metab. Cardiovasc. Dis. 2007, 17, 448-456. [CrossRef]

135. Milne, G.W. Gardner's Commercially Important Chemicals: Synonyms, Trade Names, and Properties; John Wiley \& Sons: Farnham, UK, 2005.

136. Breithaupt, D.R. Xanthophylls in poultry feeding. In Carotenoids; Birkhäuser: Basel, Switzerland, 2008; pp. 255-264. [CrossRef]

137. Viuda-Martos, M.; Sanchez-Zapata, E.; Sayas-Barberá, E.; Sendra, E.; Pérez-Álvarez, J.; Fernández-López, J. Tomato and tomato byproducts. Human health benefits of lycopene and its application to meat products: A review. Crit. Rev. Food Sci. Nutr. 2014, 54, 1032-1049. [CrossRef]

138. Srinivasan, M.; Devipriya, N.; Kalpana, K.; Menon, V.P. Lycopene: An antioxidant and radioprotector against $\gamma$-radiation-induced cellular damages in cultured human lymphocytes. Toxicology 2009, 262, 43-49. [CrossRef]

139. Devasagayam, T.; Tilak, J.; Boloor, K.; Sane, K.S.; Ghaskadbi, S.S.; Lele, R. Free radicals and antioxidants in human health: Current status and future prospects. J. Assoc. Physicians India 2004, 52, 4.

140. Rao, A.V.; Rao, L.G. Carotenoids and human health. Pharmacol. Res. 2007, 55, 207-216. [CrossRef] [PubMed]

141. Igielska-Kalwat, J.; Gościańska, J.; Nowak, I. Carotenoids as natural antioxidants. Postepy Hig. Med. Dosw. 2015, 69, 418-428. [CrossRef] [PubMed]

142. Zhang, J.; Sun, Z.; Sun, P.; Chen, T.; Chen, F. Microalgal carotenoids: Beneficial effects and potential in human health. Food Funct. 2014, 5, 413-425. [CrossRef]

143. Misawa, N. Carotenoid $\beta$-ring hydroxylase and ketolase from marine bacteria-promiscuous enzymes for synthesizing functional xanthophylls. Mar. Drugs 2011, 9, 757-771. [CrossRef]

144. Mathews-Roth, M.M. Antitumor activity of $\beta$-carotene, canthaxanthin and phytoene. Oncology 1982, 39, 33-37. [CrossRef]

145. Mordi, R.C.; Walton, J.C. Identification of products from canthaxanthin oxidation. Food Chem. 2016, 197, 836-840. [CrossRef]

146. Surai, $P$. The antioxidant properties of canthaxanthin and its potential effects in the poultry eggs and on embryonic development of the chick. Part 1. Worlds Poult. Sci. J. 2012, 68, 465-476. [CrossRef]

147. Shklar, G.; Schwartz, J. Tumor necrosis factor in experimental cancer regression with alphatocopherol, beta-carotene, canthaxanthin and algae extract. Eur. J. Cancer Clin. Oncol. 1988, 24, 839-850. [CrossRef]

148. Bendich, A.; Shapiro, S.S. Effect of $\beta$-carotene and canthaxanthin on the immune responses of the rat. J. Nutr. 1986, 116, 2254-2262. [CrossRef]

149. Abidov, M.; Ramazanov, Z.; Seifulla, R.; Grachev, S. The effects of Xanthigen ${ }^{\mathrm{TM}}$ in the weight management of obese premenopausal women with non-alcoholic fatty liver disease and normal liver fat. Diabetes Obes. Metab. 2010, 12, 72-81. [CrossRef] [PubMed]

150. Nanba, K.; Toyooka, S.; Soh, J.; Tsukuda, K.; Yamamoto, H.; Sakai, A.; Ouchida, M.; Kobayashi, N.; Matsuo, K.; Koide, N. The allelic distribution of a single nucleotide polymorphism in the PDCD5 gene locus of Japanese non-small cell lung cancer patients. Mol. Med. Rep. 2008, 1, 667-671. [CrossRef] [PubMed]

151. Gammone, M.; Riccioni, G.; D'Orazio, N. Marine carotenoids against oxidative stress: Effects on human health. Mar. Drugs 2015, 13, 6226-6246. [CrossRef] [PubMed]

152. Riccioni, G.; D’Orazio, N.; Franceschelli, S.; Speranza, L. Marine carotenoids and cardiovascular risk markers. Mar. Drugs 2011, 9, 1166-1175. [CrossRef] [PubMed]

153. Tanaka, T.; Shnimizu, M.; Moriwaki, H. Cancer chemoprevention by carotenoids. Molecules 2012, 17, 3202-3242. [CrossRef] [PubMed]

154. Peng, J.; Yuan, J.-P.; Wu, C.-F.; Wang, J.-H. Fucoxanthin, a marine carotenoid present in brown seaweeds and diatoms: Metabolism and bioactivities relevant to human health. Mar. Drugs 2011, 9, 1806-1828. [CrossRef]

155. Afolayan, A.F.; Bolton, J.J.; Lategan, C.A.; Smith, P.J.; Beukes, D.R. Fucoxanthin, tetraprenylated toluquinone and toluhydroquinone metabolites from Sargassum heterophyllum inhibit the in vitro growth of the malaria parasite Plasmodium falciparum. Z. Naturforsch. C 2008, 63, 848-852. [CrossRef]

156. Woo, M.N.; Jeon, S.M.; Shin, Y.C.; Lee, M.K.; Kang, M.A.; Choi, M.S. Anti-obese property of fucoxanthin is partly mediated by altering lipid-regulating enzymes and uncoupling proteins of visceral adipose tissue in mice. Mol. Nutr. Food Res. 2009, 53, 1603-1611. [CrossRef] 
157. Kowluru, R.A.; Menon, B.; Gierhart, D.L. Beneficial effect of zeaxanthin on retinal metabolic abnormalities in diabetic rats. Investig. Ophthalmol. Vis. Sci. 2008, 49, 1645-1651. [CrossRef]

158. Khachik, F.; de Moura, F.F.; Zhao, D.-Y.; Aebischer, C.-P.; Bernstein, P.S. Transformations of selected carotenoids in plasma, liver, and ocular tissues of humans and in nonprimate animal models. Investig. Ophthalmol. Vis. Sci. 2002, 43, 3383-3392.

159. Olmedilla, B.; Granado, F.; Blanco, I.; Vaquero, M.; Cajigal, C. Lutein in patients with cataracts and age-related macular degeneration: A long-term supplementation study. J. Sci. Food Agric. 2001, 81, 904-909. [CrossRef]

160. Gale, C.R.; Hall, N.F.; Phillips, D.I.; Martyn, C.N. Plasma antioxidant vitamins and carotenoids and age-related cataract. Ophthalmology 2001, 108, 1992-1998. [CrossRef]

161. Vu, H.T.; Robman, L.; Hodge, A.; McCarty, C.A.; Taylor, H.R. Lutein and zeaxanthin and the risk of cataract: The Melbourne visual impairment project. Investig. Ophthalmol. Vis. Sci. 2006, 47, 3783-3786. [CrossRef] [PubMed]

162. Greenstein, V.C.; Chiosi, F.; Baker, P.; Seiple, W.; Holopigian, K.; Braunstein, R.E.; Sparrow, J.R. Scotopic sensitivity and color vision with a blue-light-absorbing intraocular lens. J. Cataract Refract. Surg. 2007, 33, 667-672. [CrossRef]

163. Neelam, K.; O'Gorman, N.; Nolan, J.; O’Donovan, O.; Wong, H.B.; Eong, K.G.A.; Beatty, S. Measurement of macular pigment: Raman spectroscopy versus heterochromatic flicker photometry. Investig. Ophthalmol. Vis. Sci. 2005, 46, 1023-1032. [CrossRef]

164. Moeller, S.M.; Parekh, N.; Tinker, L.; Ritenbaugh, C.; Blodi, B.; Wallace, R.B.; Mares, J.A. Associations between intermediate age-related macular degeneration and lutein and zeaxanthin in the Carotenoids in Age-related Eye Disease Study (CAREDS): Ancillary study of the Women's Health Initiative. Arch. Ophthalmol. 2006, 124, 1151-1162. [CrossRef]

165. Christen, W.G.; Liu, S.; Glynn, R.J.; Gaziano, J.M.; Buring, J.E. Dietary carotenoids, vitamins C and E, and risk of cataract in women: A prospective study. Arch. Ophthalmol. 2008, 126, 102-109. [CrossRef]

166. Tan, J.S.; Wang, J.J.; Flood, V.; Rochtchina, E.; Smith, W.; Mitchell, P. Dietary antioxidants and the long-term incidence of age-related macular degeneration: The Blue Mountains Eye Study. Ophthalmology 2008, 115, 334-341. [CrossRef]

167. Shahina, M.; Hameed, A.; Lin, S.-Y.; Lee, R.-J.; Lee, M.-R.; Young, C.-C. Gramella planctonica sp. nov., a zeaxanthin-producing bacterium isolated from surface seawater, and emended descriptions of Gramella aestuarii and Gramella echinicola. Antonie Van Leeuwenhoek 2014, 105, 771-779. [CrossRef]

168. Huang, Y.-M.; Dou, H.-L.; Huang, F.-F.; Xu, X.-R.; Zou, Z.-Y.; Lin, X.-M. Effect of supplemental lutein and zeaxanthin on serum, macular pigmentation, and visual performance in patients with early age-related macular degeneration. BioMed Res. Int. 2015, 2015. [CrossRef]

169. Bernstein, P.S.; Li, B.; Vachali, P.P.; Gorusupudi, A.; Shyam, R.; Henriksen, B.S.; Nolan, J.M. Lutein, zeaxanthin, and meso-zeaxanthin: The basic and clinical science underlying carotenoid-based nutritional interventions against ocular disease. Prog. Retin. Eye Res. 2016, 50, 34-66. [CrossRef] [PubMed]

170. Lu, M.-S.; Fang, Y.-J.; Chen, Y.-M.; Luo, W.-P.; Pan, Z.-Z.; Zhong, X.; Zhang, C.-X. Higher intake of carotenoid is associated with a lower risk of colorectal cancer in Chinese adults: A case-control study. Eur. J. Nutr. 2015, 54, 619-628. [CrossRef] [PubMed]

171. Wang, L.; Li, B.; Pan, M.-X.; Mo, X.-F.; Chen, Y.-M.; Zhang, C.-X. Specific carotenoid intake is inversely associated with the risk of breast cancer among Chinese women. Br. J. Nutr. 2014, 111, 1686-1695. [CrossRef] [PubMed]

172. Yamaguchi, M. Role of carotenoid $\beta$-cryptoxanthin in bone homeostasis. J. Biomed. Sci. 2012, 19, 36. [CrossRef]

173. Ghodratizadeh, S.; Kanbak, G.; Beyramzadeh, M.; Dikmen, Z.G.; Memarzadeh, S.; Habibian, R. Effect of carotenoid $\beta$-cryptoxanthin on cellular and humoral immune response in rabbit. Vet. Res. Commun. 2014, 38, 59-62. [CrossRef]

174. Granado-Lorencio, F.; de Las Heras, L.; San Millán, C.; Garcia-López, F.; Blanco-Navarro, I.; Pérez-Sacristán, B.; Domínguez, G. $\beta$-Cryptoxanthin modulates the response to phytosterols in post-menopausal women carrying NPC1L1 L272L and ABCG8 A632 V polymorphisms: An exploratory study. Genes Nutr. 2014, 9, 428. [CrossRef] 
175. Chisté, R.C.; Freitas, M.; Mercadante, A.Z.; Fernandes, E. Carotenoids are effective inhibitors of in vitro hemolysis of human erythrocytes, as determined by a practical and optimized cellular antioxidant assay. J. Food Sci. 2014, 79, H1841-H1847. [CrossRef]

176. Min, K.-B.; Min, J.-Y. Association between leukocyte telomere length and serum carotenoid in US adults. Eur. J. Nutr. 2017, 56, 1045-1052. [CrossRef]

177. Liu, X.-R.; Wang, Y.-Y.; Dan, X.-G.; Kumar, A.; Ye, T.-Z.; Yu, Y.-Y.; Yang, L.-G. Anti-inflammatory potential of $\beta$-cryptoxanthin against LPS-induced inflammation in mouse Sertoli cells. Reprod. Toxicol. 2016, 60, 148-155. [CrossRef]

178. Ozaki, K.; Okamoto, M.; Fukasawa, K.; Iezaki, T.; Onishi, Y.; Yoneda, Y.; Sugiura, M.; Hinoi, E. Daily intake of $\beta$-cryptoxanthin prevents bone loss by preferential disturbance of osteoclastic activation in ovariectomized mice. J. Pharmacol. Sci. 2015, 129, 72-77. [CrossRef]

179. Raposo, M.; de Morais, A.; de Morais, R. Carotenoids from marine microalgae: A valuable natural source for the prevention of chronic diseases. Mar. Drugs 2015, 13, 5128-5155. [CrossRef] [PubMed]

180. Aasen, A.J.; Liaaen-Jensen, S. The carotenoids of flexibacteria: II. A new xanthophyll from Saprospira grandis. Acta Chem. Scand. 1966, 20, 811-819. [CrossRef] [PubMed]

181. Soontornchaiboon, W.; Joo, S.S.; Kim, S.M. Anti-inflammatory effects of violaxanthin isolated from microalga Chlorella ellipsoidea in RAW 264.7 macrophages. Biol. Pharm. Bull. 2012, 35, 1137-1144. [CrossRef] [PubMed]

182. Francis, G.; Hertzberg, S.; Andersen, K.; Liaaen-Jensen, S. New carotenoid glycosides from Oscil. Limosa. Phytochem. 1970, 9, 629-635. [CrossRef]

183. Kent, M.; Welladsen, H.M.; Mangott, A.; Li, Y. Nutritional evaluation of Australian microalgae as potential human health supplements. PLoS ONE 2015, 10, e0118985. [CrossRef]

184. Mohamed, I.; Mearns, A.S.; Fraser, K.; Hodgson, R. Biological Production of Zeaxanthin and Carotenoid Biosynthesis Control. U.S. Patents US20080293097A1, 29 January 2013.

185. Ganesan, P.; Noda, K.; Manabe, Y.; Ohkubo, T.; Tanaka, Y.; Maoka, T.; Sugawara, T.; Hirata, T. Siphonaxanthin, a marine carotenoid from green algae, effectively induces apoptosis in human leukemia (HL-60) cells. Biochim. Biophys. Acta Gen. Subj. 2011, 1810, 497-503. [CrossRef]

186. Sasso, S.; Pohnert, G.; Lohr, M.; Mittag, M.; Hertweck, C. Microalgae in the postgenomic era: A blooming reservoir for new natural products. FEMS Microbiol. Rev. 2012, 36, 761-785. [CrossRef]

187. Varela, J.C.; Pereira, H.; Vila, M.; León, R. Production of carotenoids by microalgae: Achievements and challenges. Photosynth. Res. 2015, 125, 423-436. [CrossRef]

188. Murthy, K.C.; Vanitha, A.; Rajesha, J.; Swamy, M.M.; Sowmya, P.; Ravishankar, G.A. In vivo antioxidant activity of carotenoids from Dunaliella salina-A green microalga. Life Sci. 2005, 76, 1381-1390. [CrossRef]

189. Rise, M.; Cohen, E.; Vishkautsan, M.; Cojocaru, M.; Gottlieb, H.E.; Arad, S.M. Accumulation of secondary carotenoids in Chlorella zofingiensis. J. Plant Physiol. 1994, 144, 287-292. [CrossRef]

190. Orosa, M.; Torres, E.; Fidalgo, P.; Abalde, J. Production and analysis of secondary carotenoids in green algae. J. Appl. Phycol. 2000, 12, 553-556. [CrossRef]

191. Fiedor, J.; Burda, K. Potential role of carotenoids as antioxidants in human health and disease. Nutrients 2014, 6, 466-488. [CrossRef] [PubMed]

192. Stahl, W.; Sies, H. Photoprotection by dietary carotenoids: Concept, mechanisms, evidence and future development. Mol. Nutr. Food Res. 2012, 56, 287-295. [CrossRef] [PubMed]

193. Grossman, A.R.; Bhaya, D.; Apt, K.E.; Kehoe, D.M. Light-harvesting complexes in oxygenic photosynthesis: Diversity, control, and evolution. Annu. Rev. Genet. 1995, 29, 231-288. [CrossRef]

194. Jin, E.-S.; Polle, J.E.; Lee, H.-K.; Hyun, S.-M.; Chang, M. Xanthophylls in microalgae: From biosynthesis to biotechnological mass production and application. J. Microbiol. Biotechnol. 2003, 13, 165-174.

195. Tardy, F.; Havaux, M. Photosynthesis, chlorophyll fluorescence, light-harvesting system and photoinhibition resistance of a zeaxanthindashaccumulating mutant of Arabidopsis thaliana. J. Photochem. Photobiol. B Biol. 1996, 34, 87-94. [CrossRef]

196. Rabbani, S.; Beyer, P.; Lintig, J.v.; Hugueney, P.; Kleinig, H. Induced $\beta$-carotene synthesis driven by triacylglycerol deposition in the unicellular alga Dunaliella bardawil. Plant Physiol. 1998, 116, 1239-1248. [CrossRef]

197. Hosseini Tafreshi, A.; Shariati, M. Dunaliella biotechnology: Methods and applications. J. Appl. Microbiol. 2009, 107, 14-35. [CrossRef] 
198. Wu, Z.; Duangmanee, P.; Zhao, P.; Juntawong, N.; Ma, C. The effects of light, temperature, and nutrition on growth and pigment accumulation of three Dunaliella salina strains isolated from saline soil. Jundishapur J. Microbiol. 2016, 9. [CrossRef]

199. Margalith, P. Production of ketocarotenoids by microalgae. Appl. Microbiol. Biotechnol. 1999, 51, 431-438. [CrossRef]

200. Hu, C.-C.; Lin, J.-T.; Lu, F.-J.; Chou, F.-P.; Yang, D.-J. Determination of carotenoids in Dunaliella salina cultivated in Taiwan and antioxidant capacity of the algal carotenoid extract. Food Chem. 2008, 109, 439-446. [CrossRef] [PubMed]

201. Suh, I.S.; Joo, H.-N.; Lee, C.-G. A novel double-layered photobioreactor for simultaneous Haematococcus pluvialis cell growth and astaxanthin accumulation. J. Biotechnol. 2006, 125, 540-546. [CrossRef] [PubMed]

202. Ip, P.-F.; Chen, F. Production of astaxanthin by the green microalga Chlorella zofingiensis in the dark. Process Biochem. 2005, 40, 733-738. [CrossRef]

203. Inbaraj, B.S.; Chien, J.; Chen, B. Improved high performance liquid chromatographic method for determination of carotenoids in the microalga Chlorella pyrenoidosa. J. Chromatogr. 2006, 1102, 193-199. [CrossRef] [PubMed]

204. Sánchez, J.; Fernández, J.; Acién, F.; Rueda, A.; Pérez-Parra, J.; Molina, E. Influence of culture conditions on the productivity and lutein content of the new strain Scenedesmus almeriensis. Process Biochem. 2008, 43, 398-405. [CrossRef]

205. Sánchez, J.; Fernández-Sevilla, J.; Acién, F.; Cerón, M.; Pérez-Parra, J.; Molina-Grima, E. Biomass and lutein productivity of Scenedesmus almeriensis: Influence of irradiance, dilution rate and temperature. Appl. Microbiol. Biotechnol. 2008, 79, 719-729. [CrossRef]

206. Lordan, S.; Ross, R.P.; Stanton, C. Marine bioactives as functional food ingredients: Potential to reduce the incidence of chronic diseases. Mar. Drugs 2011, 9, 1056-1100. [CrossRef]

207. Mohammed, M.K.; Mohd, M.K. Production of carotenoids (antioxidants/colourant) in Spirulina platensis in response to indole acetic acid (IAA). Int. J. Eng. Sci. Technol. 2011, 3, 4973-4979.

208. Plaza, M.; Herrero, M.; Cifuentes, A.; Ibanez, E. Innovative natural functional ingredients from microalgae. J. Agric. Food Chem. 2009, 57, 7159-7170. [CrossRef]

209. Saleha, A.; Dhar, D.; Singh, P. Comparative pigment profiles of different Spirulina strains. Res. Biotech. 2011, 2.

210. Kleinegris, D.M.; Janssen, M.; Brandenburg, W.A.; Wijffels, R.H. Continuous production of carotenoids from Dunaliella salina. Enzyme Microb. Technol. 2011, 48, 253-259. [CrossRef]

211. Holeton, C.; Lindell, K.; Holmborn, T.; Hogfors, H.; Gorokhova, E. Decreased astaxanthin at high feeding rates in the calanoid copepod Acartia bifilosa. J. Plankton Res. 2009, 31, 661-668. [CrossRef]

212. Kim, S.M.; Jung, Y.-J.; Kwon, O.-N.; Cha, K.H.; Um, B.-H.; Chung, D.; Pan, C.-H. A potential commercial source of fucoxanthin extracted from the microalga Phaeodactylum tricornutum. Appl. Biochem. Biotechnol. 2012, 166, 1843-1855. [CrossRef] [PubMed]

213. Graziani, G.; Schiavo, S.; Nicolai, M.A.; Buono, S.; Fogliano, V.; Pinto, G.; Pollio, A. Microalgae as human food: Chemical and nutritional characteristics of the thermo-acidophilic microalga Galdieria sulphuraria. Food Funct. 2013, 4, 144-152. [CrossRef] [PubMed]

214. Vaquero, I.; Vázquez, M.; Ruiz-Domínguez, M.; Vílchez, C. Enhanced production of a lutein-rich acidic environment microalga. J. Appl. Microbiol. 2014, 116, 839-850. [CrossRef]

215. Xia, S.; Wang, K.; Wan, L.; Li, A.; Hu, Q.; Zhang, C. Production, characterization, and antioxidant activity of fucoxanthin from the marine diatom Odontella aurita. Mar. Drugs 2013, 11, 2667-2681. [CrossRef]

216. Kim, S.M.; Kang, S.-W.; Kwon, O.-N.; Chung, D.; Pan, C.-H. Fucoxanthin as a major carotenoid in Isochrysis aff. galbana: Characterization of extraction for commercial application. J. Korean Soc. Appl. Biol. Chem. 2012, 55, 477-483. [CrossRef]

217. De Miguel, T.; Sieiro, C.; Poza, M.; Villa, T.G. Isolation and taxonomic study of a new canthaxanthin-containing bacterium, Gordonia jacobaea MV-1 sp. nov. Int. Microbiol. 2000, 3, 107-111.

218. Bhosale, P.; Bernstein, P.S. Microbial xanthophylls. Appl. Microbiol. Biotechnol. 2005, 68, 445-455. [CrossRef]

219. Khodaiyan, F.; Razavi, S.H.; Emam-Djomeh, Z.; Mousavi, S.M.A.; Hejazi, M.A. Effect of culture conditions on canthaxanthin production by Dietzia natronolimnaea HS-1. J. Microbiol. Biotechnol. 2007, 17, 195.

220. Nelis, H.J.; De Leenheer, A. Microbial sources of carotenoid pigments used in foods and feeds. J. Appl. Bacteriol. 1991, 70, 181-191. [CrossRef] 
221. Asker, D.; Ohta, Y. Production of canthaxanthin by Haloferax alexandrinus under non-aseptic conditions and a simple, rapid method for its extraction. Appl. Microbiol. Biotechnol. 2002, 58, 743-750. [CrossRef] [PubMed]

222. Yokoyama, A.; Izumida, H.; Miki, W. Production of astaxanthin and 4-ketozeaxanthin by the marine bacterium, Agrobacterium aurantiacum. Biosci. Biotechnol. Biochem. 1994, 58, 1842-1844. [CrossRef]

223. Hamidi, M.; Abdin, M.; Nazemyieh, H.; Hejazi, M.; Hejazi, M. Optimization of total carotenoid production by Halorubrum sp. TBZ126 using response surface methodology. J. Microb. Biochem. Technol. 2014, 6, 286-294. [CrossRef]

224. Mata-Gómez, L.C.; Montañez, J.C.; Méndez-Zavala, A.; Aguilar, C.N. Biotechnological production of carotenoids by yeasts: An overview. Microb. Cell Fact. 2014, 13, 12. [CrossRef]

225. Hameed, A.; Shahina, M.; Lin, S.-Y.; Lai, W.-A.; Hsu, Y.-H.; Liu, Y.-C.; Young, C.-C. Aquibacter zeaxanthinifaciens gen. nov., sp. nov., a zeaxanthin-producing bacterium of the family Flavobacteriaceae isolated from surface seawater, and emended descriptions of the genera Aestuariibaculum and Gaetbulibacter. Int. J. Syst. Evol. Microbiol. 2014, 64, 138-145. [CrossRef]

226. Takaichi, S.; Mochimaru, M.; Maoka, T. Presence of free myxol and 4-hydroxymyxol and absence of myxol glycosides in Anabaena variabilis ATCC 29413, and proposal of a biosynthetic pathway of carotenoids. Plant Cell Physiol. 2006, 47, 211-216. [CrossRef]

227. Kim, S.; Chen, J.; Cheng, T.; Gindulyte, A.; He, J.; He, S.; Li, Q.; Shoemaker, B.A.; Thiessen, P.A.; Yu, B. PubChem 2019 update: Improved access to chemical data. Nucleic Acids Res. 2018, 47, D1102-D1109. [CrossRef]

228. Jehlička, J.; Edwards, H.; Oren, A. Bacterioruberin and salinixanthin carotenoids of extremely halophilic Archaea and Bacteria: A Raman spectroscopic study. Spectrochim. Acta A Mol. Biomol. Spectrosc. 2013, 106, 99-103. [CrossRef]

229. Balashov, S.P.; Imasheva, E.S.; Lanyi, J.K. Induced chirality of the light-harvesting carotenoid salinixanthin and its interaction with the retinal of xanthorhodopsin. Biochemistry 2006, 45, 10998-11004. [CrossRef]

230. Asker, D.; Beppu, T.; Ueda, K. Mesoflavibacter zeaxanthinifaciens gen. nov., sp. nov., a novel zeaxanthin-producing marine bacterium of the family Flavobacteriaceae. Syst. Appl. Microbiol. 2007, 30, 291-296. [CrossRef]

231. Asker, D.; Beppu, T.; Ueda, K. Zeaxanthinibacter enoshimensis gen. nov., sp. nov., a novel zeaxanthin-producing marine bacterium of the family Flavobacteriaceae, isolated from seawater off Enoshima Island, Japan. Int. J. Syst. Evol. Microbiol. 2007, 57, 837-843. [CrossRef] [PubMed]

232. Hameed, A.; Arun, A.; Ho, H.-P.; Chang, C.-M.J.; Rekha, P.; Lee, M.-R.; Singh, S.; Young, C.-C. Supercritical carbon dioxide micronization of zeaxanthin from moderately thermophilic bacteria Muricauda lutaonensis CC-HSB-11T. J. Agric. Food Chem. 2011, 59, 4119-4124. [CrossRef] [PubMed]

233. Hameed, A.; Shahina, M.; Lin, S.-Y.; Sridhar, K.R.; Young, L.-S.; Lee, M.-R.; Chen, W.-M.; Chou, J.-H.; Young, C.-C. Siansivirga zeaxanthinifaciens gen. nov., sp. nov., a novel zeaxanthin-producing member of the family Flavobacteriaceae isolated from coastal seawater of Taiwan. FEMS Microbiol. Lett. 2012, 333, 37-45. [CrossRef] [PubMed]

234. Venugopal, V. Marine Products for Healthcare: Functional and Bioactive Nutraceutical Compounds from the Ocean; Taylor \& Francis Group: Boca Raton, FL, USA, 2008.

235. Bule, M.H.; Ahmed, I.; Maqbool, F.; Bilal, M.; Iqbal, H.M.N. Microalgae as a source of high-value bioactive compounds. Front. Biosci. 2018, 10, 197-216.

236. Guedes, A.C.; Amaro, H.M.; Malcata, F.X. Microalgae as sources of high added-value compounds-a brief review of recent work. Biotechnol. Prog. 2011, 27, 597-613. [CrossRef]

237. Del Campo, J.A.; García-González, M.; Guerrero, M.G. Outdoor cultivation of microalgae for carotenoid production: Current state and perspectives. Appl. Microbiol. Biotechnol. 2007, 74, 1163-1174. [CrossRef]

238. Stutz, H.; Bresgen, N.; Eckl, P. Analytical tools for the analysis of $\beta$-carotene and its degradation products. Free Radic. Res. 2015, 49, 650-680. [CrossRef]

239. Englert, M.; Hammann, S.; Vetter, W. Isolation of $\beta$-carotene, $\alpha$-carotene and lutein from carrots by countercurrent chromatography with the solvent system modifier benzotrifluoride. J. Chromatogr. 2015, 1388, 119-125. [CrossRef]

240. Goodwin, T.W. The Biochemistry of the Carotenoids, 2nd ed.; Springer: Heidelberg, Germany, 1980; Volume 1.

241. Britton, G.; Liaaen-Jensen, S.; Pfander, H. Carotenoids: Handbook; Birkhäuser: Basel, Switzerland, 2012. 
242. Yokoyama, A.; Adachi, K.; Shizuri, Y. New carotenoid glucosides, astaxanthin glucoside and adonixanthin glucoside, isolated from the astaxanthin-producing marine bacterium, Agrobacterium aurantiacum. J. Nat. Prod. 1995, 58, 1929-1933. [CrossRef]

243. Yokoyama, A.; Izumida, H.; Shizuri, Y. New carotenoid sulfates isolated from a marine bacterium. Biosci. Biotechnol. Biochem. 1996, 60, 1877-1878. [CrossRef]

244. Yokoyama, A.; Miki, W.; Izumida, H.; Shizuri, Y. New trihydroxy-keto-carotenoids isolated from an astaxanthin-producing marine bacterium. Biosci. Biotechnol. Biochem. 1996, 60, 200-203. [CrossRef] [PubMed]

245. Shindo, K.; Misawa, N.J.M.d. New and rare carotenoids isolated from marine bacteria and their antioxidant activities. Mar. Drugs 2014, 12, 1690-1698. [CrossRef] [PubMed]

246. Casillo, A.; Lanzetta, R.; Parrilli, M.; Corsaro, M.M. Exopolysaccharides from marine and marine extremophilic bacteria: Structures, properties, ecological roles and applications. Mar. Drugs 2018, 16, 69. [CrossRef] [PubMed]

247. Nwodo, U.U.; Green, E.; Okoh, A.I. Bacterial exopolysaccharides: Functionality and prospects. Int. J. Mol. Sci. 2012, 13, 14002-14015. [CrossRef]

248. Delbarre-Ladrat, C.; Sinquin, C.; Lebellenger, L.; Zykwinska, A.; Colliec-Jouault, S. Exopolysaccharides produced by marine bacteria and their applications as glycosaminoglycan-like molecules. Front. Chem. 2014, 2, 85. [CrossRef]

249. Wang, J.; Hu, S.; Nie, S.; Yu, Q.; Xie, M. Reviews on mechanisms of in vitro antioxidant activity of polysaccharides. Oxid. Med. Cell. Longev. 2016, 2016. [CrossRef]

250. Gülçin, İ. Antioxidant and antiradical activities of L-carnitine. Life Sci. 2006, 78, 803-811. [CrossRef]

251. Liu, W.; Wang, H.; Pang, X.; Yao, W.; Gao, X. Characterization and antioxidant activity of two low-molecular-weight polysaccharides purified from the fruiting bodies of Ganoderma lucidum. Int. J. Biol. Macromol. 2010, 46, 451-457. [CrossRef]

252. Manivasagan, P.; Kim, S.-K. Extracellular polysaccharides produced by marine bacteria. Adv. Food Nutr. Res. 2014, 72, 79-94.

253. Wu, S.; Liu, G.; Jin, W.; Xiu, P.; Sun, C. Antibiofilm and anti-infection of a marine bacterial exopolysaccharide against Pseudomonas aeruginosa. Front. Microbiol. 2016, 7, 102. [CrossRef]

254. Fang, Y.; Ahmed, S.; Liu, S.; Wang, S.; Lu, M.; Jiao, Y. Optimization of antioxidant exopolysaccharidess production by Bacillus licheniformis in solid state fermentation. Carbohydr. Polym. 2013, 98, 1377-1382. [CrossRef] [PubMed]

255. Mohamed, S.; Shimaa, R.; El Awady, M.; El Sayed, O. Screening of bacterial antioxidant exopolysaccharides isolated from Egyptian habitats. J. Chem. Pharm. Res. 2015, 7, 980-986.

256. Selim, M.S.; Mohamed, S.S.; Asker, M.M.; Salama, A.A.; Abdallah, H.M.; Yassen, N.N. Production and characterization of exopolysaccharide from marine Bacillus sp. MSHN2016 with studying its effect on isoniazid/rifampicin-induced hepatic and renal toxicities in rats. J. Appl. Pharm. Sci. 2018, 8, 1-11. [CrossRef]

257. Shivale, N.; Marar, T.; Samant, M.; Harmalkar, M. Screening of Antioxidant Activity of marine bacteria isolated from marine soil obtained from North-West coastal region of India. Int. J. Biol. Pharm. Allied Sci. 2018, 7. [CrossRef]

258. Sran, K.S.; Bisht, B.; Mayilraj, S.; Choudhury, A.R. Structural characterization and antioxidant potential of a novel anionic exopolysaccharide produced by marine Microbacterium aurantiacum FSW-25. Int. J. Biol. Macromol. 2019, 131, 343-352. [CrossRef]

259. Sun, M.-L.; Zhao, F.; Shi, M.; Zhang, X.-Y.; Zhou, B.-C.; Zhang, Y.-Z.; Chen, X.-L. Characterization and biotechnological potential analysis of a new exopolysaccharide from the Arctic marine bacterium Polaribacter sp. SM1127. Sci. Rep. 2015, 5, 18435. [CrossRef]

260. Guo, S.; Mao, W.; Han, Y.; Zhang, X.; Yang, C.; Chen, Y.; Chen, Y.; Xu, J.; Li, H.; Qi, X. Structural characteristics and antioxidant activities of the extracellular polysaccharides produced by marine bacterium Edwardsiella tarda. Bioresour. Technol. 2010, 101, 4729-4732. [CrossRef]

261. Wang, C.; Fan, Q.; Zhang, X.; Lu, X.; Xu, Y.; Zhu, W.; Zhang, J.; Hao, W.; Hao, L. Isolation, characterization, and pharmaceutical applications of an exopolysaccharide from Aerococcus Uriaeequi. Mar. Drugs 2018, 16, 337. [CrossRef]

262. Priyanka, P.; Arun, A.; Young, C.; Rekha, P. Prospecting exopolysaccharides produced by selected bacteria associated with marine organisms for biotechnological applications. Chin. J. Polym. Sci. 2015, 33, 236-244. [CrossRef] 
263. El-Newary, S.A.; Ibrahim, A.Y.; Asker, M.S.; Mahmoud, M.G.; El Awady, M.E. Production, characterization and biological activities of acidic exopolysaccharide from marine Bacillus amyloliquefaciens 3MS 2017. Asian Pac. J. Trop. Med. 2017, 10, 652-662. [CrossRef]

264. Ye, S.; Liu, F.; Wang, J.; Wang, H.; Zhang, M. Antioxidant activities of an exopolysaccharide isolated and purified from marine Pseudomonas PF-6. Carbohydr. Polym. 2012, 87, 764-770. [CrossRef]

265. Sun, M.-L.; Liu, S.-B.; Qiao, L.-P.; Chen, X.-L.; Pang, X.; Shi, M.; Zhang, X.-Y.; Qin, Q.-L.; Zhou, B.-C.; Zhang, Y.-Z. A novel exopolysaccharide from deep-sea bacterium Zunongwangia profunda SM-A87: Low-cost fermentation, moisture retention, and antioxidant activities. Appl. Microbiol. Biotechnol. 2014, 98, 7437-7445. [CrossRef] [PubMed]

266. Delattre, C.; Pierre, G.; Laroche, C.; Michaud, P. Production, extraction and characterization of microalgal and cyanobacterial exopolysaccharides. Biotechnol. Adv. 2016, 34, 1159-1179. [CrossRef] [PubMed]

267. Gaignard, C.; Gargouch, N.; Dubessay, P.; Delattre, C.; Pierre, G.; Laroche, C.; Fendri, I.; Abdelkafi, S.; Michaud, P. New horizons in culture and valorization of red microalgae. Biotechnol. Adv. 2018, 37, 193-222. [CrossRef] [PubMed]

268. Pignolet, O.; Jubeau, S.; Vaca-Garcia, C.; Michaud, P. Highly valuable microalgae: Biochemical and topological aspects. J. Ind. Microbiol. Biotechnol. 2013, 40, 781-796. [CrossRef]

269. Markou, G.; Nerantzis, E. Microalgae for high-value compounds and biofuels production: A review with focus on cultivation under stress conditions. Biotechnol. Adv. 2013, 31, 1532-1542. [CrossRef]

270. Malanga, G.; Puntarulo, S. Oxidative stress and antioxidant content in Chlorella vulgaris after exposure to ultraviolet-B radiation. Physiol. Plant. 1995, 94, 672-679. [CrossRef]

271. Wang, H.; Liu, Y.; Qi, Z.; Wang, S.; Liu, S.; Li, X.; Wang, H.; Xia, X. An overview on natural polysaccharides with antioxidant properties. Curr. Med. Chem. 2013, 20, 2899-2913. [CrossRef]

272. Lo, T.C.-T.; Chang, C.A.; Chiu, K.-H.; Tsay, P.-K.; Jen, J.-F. Correlation evaluation of antioxidant properties on the monosaccharide components and glycosyl linkages of polysaccharide with different measuring methods. Carbohydr. Polym. 2011, 86, 320-327. [CrossRef]

273. Shen, S.-G.; Jia, S.-R.; Wu, Y.-K.; Yan, R.-R.; Lin, Y.-H.; Zhao, D.-X.; Han, P.-P. Effect of culture conditions on the physicochemical properties and antioxidant activities of polysaccharides from Nostoc flagelliforme. Carbohydr. Polym. 2018, 198, 426-433. [CrossRef]

274. Herrero, M.; Martín-Álvarez, P.J.; Senorans, F.J.; Cifuentes, A.; Ibáñez, E. Optimization of accelerated solvent extraction of antioxidants from Spirulina platensis microalga. Food Chem. 2005, 93, 417-423. [CrossRef]

275. Li, L.; Gao, Y.-T.; Dai, Y.; Yang, Y.-L.; Wang, X.-M. Scavenging Effects of Spirulina and Polysaccharides Spirulina Platensis on Active Oxygens and Its Antioxidation in vitro. Chem. Bioeng. 2007, 3.

276. Chen, B.; You, W.; Huang, J.; Yu, Y.; Chen, W. Isolation and antioxidant property of the extracellular polysaccharide from Rhodella reticulata. World J. Microbiol. Biotechnol. 2010, 26, 833-840. [CrossRef]

277. Wang, S.Y.; Jiang, Y.; Meng, C.; Ouyang, Y.H.; Lin, X.Z. Preparation of extracellular polysaccharide from fermentation liquor of marine microalgae Schizochytrium and study on the bioactivities. J. Fuzhou Univ. 2011, 5.

278. Sun, Y.; Wang, H.; Guo, G.; Pu, Y.; Yan, B. The isolation and antioxidant activity of polysaccharides from the marine microalgae Isochrysis galbana. Carbohydr. Polym. 2014, 113, 22-31. [CrossRef]

279. Abdalla, A.; Tirzite, D.; Tirzitis, G.; Roozen, J. Antioxidant activity of 1, 4-dihydropyridine derivatives in $\beta$-carotene-methyl linoleate, sunflower oil and emulsions. Food Chem. 1999, 66, 189-195. [CrossRef]

280. Fimbres-Olivarria, D.; Carvajal-Millan, E.; Lopez-Elias, J.A.; Martinez-Robinson, K.G.; Miranda-Baeza, A.; Martinez-Cordova, L.R.; Enriquez-Ocaña, F.; Valdez-Holguin, J.E. Chemical characterization and antioxidant activity of sulfated polysaccharides from Navicula sp. Food Hydrocoll. 2018, 75, 229-236. [CrossRef]

281. Sun, L.; Wang, L.; Li, J.; Liu, H. Characterization and antioxidant activities of degraded polysaccharides from two marine Chrysophyta. Food Chem. 2014, 160, 1-7. [CrossRef]

282. Geresh, S.; Arad, S. The extracellular polysaccharides of the red microalgae: Chemistry and rheology. Bioresour. Technol. 1991, 38, 195-201. [CrossRef]

283. Wu, R.; Wu, C.; Liu, D.; Yang, X.; Huang, J.; Zhang, J.; Liao, B.; He, H.; Li, H. Overview of antioxidant peptides derived from marine resources: The sources, characteristic, purification, and evaluation methods. Appl. Biochem. Biotechnol. 2015, 176, 1815-1833. [CrossRef]

284. Pihlanto-Leppälä, A. Bioactive peptides derived from bovine whey proteins: Opioid and ace-inhibitory peptides. Trends Food Sci. Technol. 2000, 11, 347-356. [CrossRef] 
285. Kim, S.-K.; Kim, Y.-T.; Byun, H.-G.; Park, P.-J.; Ito, H. Purification and characterization of antioxidative peptides from bovine skin. BMB Rep. 2001, 34, 219-224.

286. Jung, W.-K.; Rajapakse, N.; Kim, S.-K. Antioxidative activity of a low molecular weight peptide derived from the sauce of fermented blue mussel, Mytilus edulis. Eur. Food Res. Technol. 2005, 220, 535-539. [CrossRef]

287. Suetsuna, K.; Maekawa, K.; Chen, J.-R. Antihypertensive effects of Undaria pinnatifida (wakame) peptide on blood pressure in spontaneously hypertensive rats. J. Nutr. Biochem. 2004, 15, 267-272. [CrossRef] [PubMed]

288. Rong Chen, J.; Suetsuna, K.; Yamauchi, F. Isolation and characterization of immunostimulative peptides from soybean. J. Nutr. Biochem. 1995, 6, 310-313. [CrossRef]

289. Tsuruki, T.; Kishi, K.; Takahashi, M.; Tanaka, M.; Matsukawa, T.; Yoshikawa, M. Soymetide, an immunostimulating peptide derived from soybean $\beta$-conglycinin, is an fMLP agonist. FEBS Lett. 2003, 540, 206-210. [CrossRef]

290. Ngo, D.-H.; Kim, S.-K. Marine bioactive peptides as potential antioxidants. Curr. Protein Pept. Sci. 2013, 14, 189-198. [CrossRef]

291. Sheih, I.-C.; Wu, T.-K.; Fang, T.J. Antioxidant properties of a new antioxidative peptide from algae protein waste hydrolysate in different oxidation systems. Bioresour. Technol. 2009, 100, 3419-3425. [CrossRef]

292. Renaud, S.; Zhou, H.; Parry, D.; Thinh, L.-V.; Woo, K. Effect of temperature on the growth, total lipid content and fatty acid composition of recently isolated tropical microalgae Isochrysis sp., Nitzschia closterium, Nitzschia paleacea, and commercial species Isochrysis sp. (clone T. ISO). J. Appl. Phycol. 1995, 7, 595-602. [CrossRef]

293. Kang, K.H.; Qian, Z.J.; Ryu, B.; Karadeniz, F.; Kim, D.; Kim, S.-K. Antioxidant peptides from protein hydrolysate of microalgae Navicula incerta and their protective effects in HepG2/CYP2E1 cells induced by ethanol. Phytother. Res. 2012, 26, 1555-1563. [CrossRef]

294. Chrapusta, E.; Kaminski, A.; Duchnik, K.; Bober, B.; Adamski, M.; Bialczyk, J. Mycosporine-like amino acids: Potential health and beauty ingredients. Mar. Drugs 2017, 15, 326. [CrossRef] [PubMed]

295. Huang, C.; Zhang, Z.; Cui, W. Marine-Derived Natural Compounds for the Treatment of Parkinson's Disease. Mar. Drugs 2019, 17, 221. [CrossRef] [PubMed]

296. Castellano, I.; Seebeck, F.P. On ovothiol biosynthesis and biological roles: From life in the ocean to therapeutic potential. Nat. Prod. Rep. 2018, 35, 1241-1250. [CrossRef] [PubMed]

297. Selman-Reimer, S.; Duhe, R.; Stockman, B.; Selman, B. L-1-N-methyl-4-mercaptohistidine disulfide, a potential endogenous regulator in the redox control of chloroplast coupling factor 1 in Dunaliella. J. Biol. Chem. 1991, 266, 182-188.

298. O'neill, E.C.; Trick, M.; Hill, L.; Rejzek, M.; Dusi, R.G.; Hamilton, C.J.; Zimba, P.V.; Henrissat, B.; Field, R.A. The transcriptome of Euglena gracilis reveals unexpected metabolic capabilities for carbohydrate and natural product biochemistry. Mol. Biosyst. 2015, 11, 2808-2820. [CrossRef]

299. Leroux, A.E.; Krauth-Siegel, R.L. Thiol redox biology of trypanosomatids and potential targets for chemotherapy. Mol. Biochem. Parasit. 2016, 206, 67-74. [CrossRef]

300. Jiang, C.-S.; Müller, W.E.; Schröder, H.C.; Guo, Y.-W. Disulfide-and multisulfide-containing metabolites from marine organisms. Chem. Rev. 2011, 112, 2179-2207. [CrossRef]

301. Turner, E.; Klevit, R.; Hager, L.J.; Shapiro, B.M. Ovothiols, a family of redox-active mercaptohistidine compounds from marine invertebrate eggs. Biochem. 1987, 26, 4028-4036. [CrossRef]

302. Turner, E.; Klevit, R.; Hopkins, P.; Shapiro, B. Ovothiol: A novel thiohistidine compound from sea urchin eggs that confers NAD (P) H-O2 oxidoreductase activity on ovoperoxidase. J. Biol. Chem. 1986, 261, 13056-13063.

303. Holler, T.P.; Hopkins, P.B. Ovothiols as biological antioxidants. The thiol groups of ovothiol and glutathione are chemically distinct. J. Am. Chem. Soc. 1988, 110, 4837-4838. [CrossRef]

304. Braunshausen, A.; Seebeck, F.P. Identification and characterization of the first ovothiol biosynthetic enzyme. J. Am. Chem. Soc. 2011, 133, 1757-1759. [CrossRef] [PubMed]

305. Castellano, I.; Migliaccio, O.; D'Aniello, S.; Merlino, A.; Napolitano, A.; Palumbo, A. Shedding light on ovothiol biosynthesis in marine metazoans. Sci. Rep. 2016, 6, 21506. [CrossRef] [PubMed]

(C) 2019 by the authors. Licensee MDPI, Basel, Switzerland. This article is an open access article distributed under the terms and conditions of the Creative Commons Attribution (CC BY) license (http://creativecommons.org/licenses/by/4.0/). 